\title{
Ethnopharmacological Survey of Medicinal Plants Used by Traditional Healers and Indigenous People in Chittagong Hill Tracts, Bangladesh, for the Treatment of Snakebite
}

\author{
Mohammad Fahim Kadir, ${ }^{1,2}$ James Regun Karmoker, ${ }^{2}$ Md. Rashedul Alam, ${ }^{1}$ \\ Syeda Rawnak Jahan, ${ }^{1}$ Sami Mahbub, ${ }^{2}$ and M. M. K. Mia ${ }^{3}$ \\ ${ }^{1}$ Department of Pharmaceutical Technology, Faculty of Pharmacy, University of Dhaka, Dhaka 1000, Bangladesh \\ ${ }^{2}$ Department of Pharmacy, University of Asia Pacific, Dhaka 1209, Bangladesh \\ ${ }^{3}$ Bangladesh National Herbarium, Bangladesh \\ Correspondence should be addressed to Mohammad Fahim Kadir; fakaphdu@gmail.com
}

Received 27 November 2014; Accepted 15 January 2015

Academic Editor: Rainer W. Bussmann

Copyright (c) 2015 Mohammad Fahim Kadir et al. This is an open access article distributed under the Creative Commons Attribution License, which permits unrestricted use, distribution, and reproduction in any medium, provided the original work is properly cited.

\begin{abstract}
Snakebites are common in tropical countries like Bangladesh where most snakebite victims dwell in rural areas. Among the management options after snakebite in Bangladesh, snake charmers (Ozha in Bengali language) are the first contact following a snakebite for more than $80 \%$ of the victims and they are treated mostly with the help of some medicinal plants. Our aim of the study is to compile plants used for the treatment of snakebite occurrence in Bangladesh. The field survey was carried out in a period of almost 3 years. Fieldwork was undertaken in Chittagong Hill Tracts, Bangladesh, including Chittagong, Rangamati, Bandarban, and Khagrachari. Open-ended and semistructured questionnaire was used to interview a total of 110 people including traditional healers and local people. A total of 116 plant species of 48 families were listed. Leaves were the most cited plant part used against snake venom. Most of the reported species were herb in nature and paste mostly used externally is the mode of preparation. The survey represents the preliminary information of certain medicinal plants having neutralizing effects against snake venoms, though further phytochemical investigation, validation, and clinical trials should be conducted before using these plants as an alternative to popular antivenom.
\end{abstract}

\section{Introduction}

Snakebite, caused by a bite from a snake, is an accidental injury, which results in puncture wounds inflicted by the animal's fangs and sometimes causes envenomation. Snakes are carnivorous vertebrates of the class Reptilia, order Squamata, and suborder Serpentes. Snakes usually kill their prey with constriction rather than venom, though venomous snakes can be found on every continent except Antarctica [1]. 15\% of the almost 3000 known species of snakes are venomous [2-4] and, in South Asia, four species were thought to be responsible for causing almost all the deadly cases of venomous snakebites which are referred to as the "big four," which include the Indian cobra (Naja naja), the common krait (Bungarus caeruleus), Russell's viper (Daboia russelii), and the saw-scaled or carpet viper (Echis carinatus). However, other venomous snakes may also be found in this area [5-7] and thus represent a major cause of morbidity and mortality to humans [8-11]. Exact numbers on the global prevalence of snakebites and the percentage of severe or fatal cases are largely unknown [12]. However, at least 421,000-1,841,000 envenoming and 20,000-94,000 deaths occur worldwide each year due to snakebite [1]. According to Williams et al. [13] these events surpass the number of deaths from tropical diseases such as hemorrhagic fever, dengue, cholera, leishmaniasis, and the Chagas disease.

Incidence of snakebites in Bangladesh is very high like other tropical countries of Southeast Asia [1]. Here most snakebite victims dwelling in rural areas are farmers, fishermen, and hunters [7-9] and also there are a high number of 


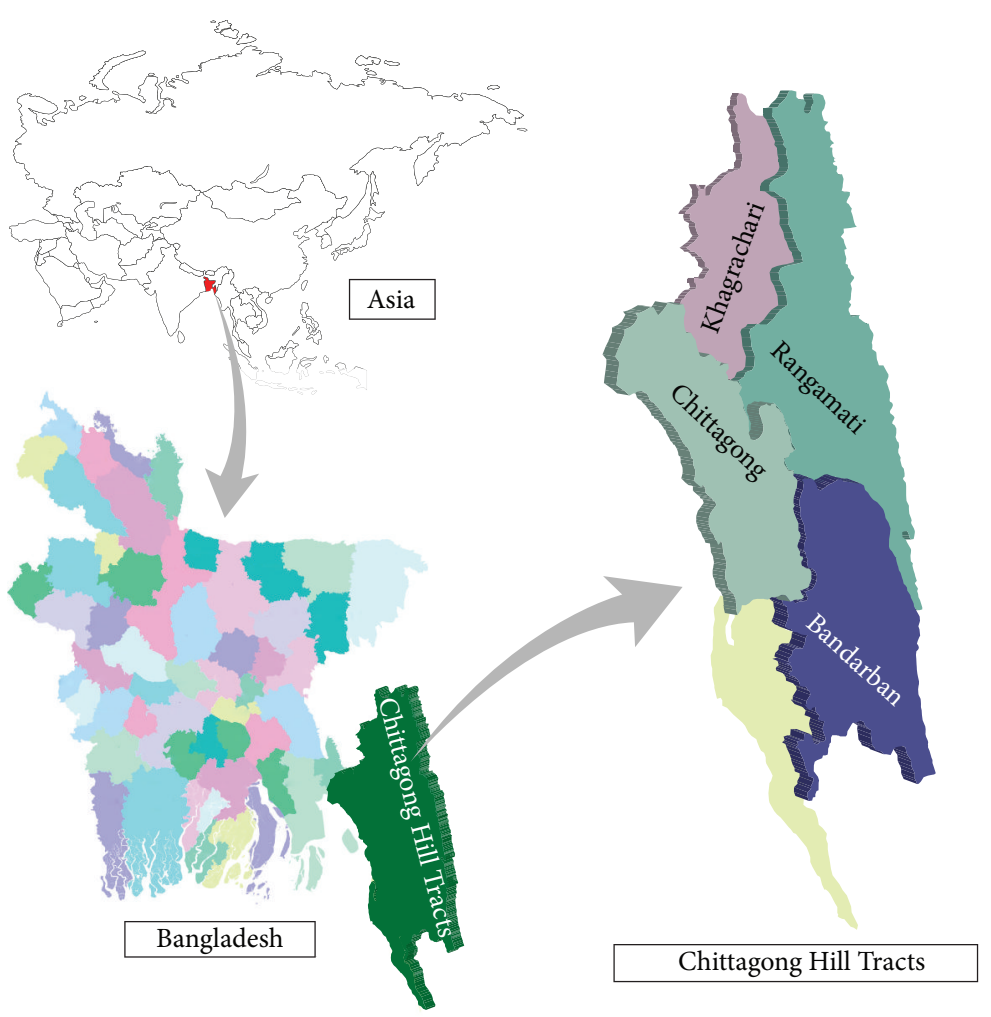

Figure 1: Map of Chittagong Hill Tracts, Bangladesh.

snakebite occurrences that happened at their homes as most of the snakes are nocturnal animals and poor people have the practice of sleeping on the floor [7]. An epidemiological study estimated about 8000 snakebites per year with $22 \%$ mortality which has been identified to be one of the highest in the world $[10,14]$. Nonetheless, there are approximately 80 species of snakes found in Bangladesh; among them only few are venomous. These are cobra, krait, Russell's viper, sawscaled viper, green snakes, and sea snakes. However, most of the bites are reported by nonvenomous snakes and even as many as $40 \%$ bites inflicted by venomous snakes do not produce signs of envenoming [15].

Antivenom is the only therapeutic agent against snake venom available throughout the world. These antivenoms have highly effective neutralizing systemic effects but show some limitations in the inhibition of the local disorders [16, 17] and also a chief drawback of serum therapy is its excessive cost and likelihood that victims are often at some distance away from availability of modern treatment when bitten as antivenom treatment should be sought as soon as possible for their potential efficacy. Moreover, there is a crisis in the quality and supply of antivenom serum in the rural areas where most incidences of snakebites occurred [18]. These problems could be subsided by using traditional plant based treatment since approximately 700 plant species are known to possess potential antivenom [19-22].

Ethnopharmacological survey is important for the conservation and utilization of biological resources [23] since of the 422,000 flowering plants found globally [24] more than
50,000 are used for medicinal purposes [25] and these plants contribute to $33 \%$ of drugs produced worldwide [26]. To date approximately more than 6,000 species of indigenous and naturalized plants have been identified out of which more than one thousand contain medicinally useful chemical substances [27, 28]. Due to this rich diversity apparently more than $80 \%$ of the Bangladeshi use alternative (Ayurveda, Siddha, Unani, and Homeopathy) medicines for their healthcare and herbs constitute a major source of these alternative systems of medicine $[29,30]$.

Several ethnobotanical investigations have been carried out at different parts of the world to explore the herbal treatment against snakebite [16, 31-35]. But there are very few ethnobotanical surveys carried out in Bangladesh to explore the medicinal plants used here in the treatment of snakebite. The present study was conducted in order to document the traditional knowledge of the medicinal plants used by the traditional healers of Bangladesh for treating against snakebite.

\section{Materials and Methods}

2.1. Study Area. The study was conducted in four districts in Chittagong Hill Tracts (Figure 1) in Bangladesh which is located in South Asia and bordered by India and Myanmar and by the Bay of Bengal to the south (latitudes $20^{\circ}$ and $27^{\circ} \mathrm{N}$ and longitudes $88^{\circ}$ and $93^{\circ} \mathrm{E}$ ) with population over 162 million having 35 smaller groups of indigenous people. The vegetation type of the study area falls under tropical evergreen and semievergreen forests. More than 3 million people live in this 
study area and these people mostly depend on the resources coming from the hilly areas [36].

2.2. Informants and Ethnomedicinal Data Collection. The survey was conducted in the official language of Bangladesh, Bengali language, from January 2010 to December 2012. Objectives of the survey were explained to the local communities during social gatherings arranged by local people familiar with well-known traditional health practitioners (THPs). While meeting with indigenous populations who had mother language different from the state language, help from local bilingual translator was taken. Special emphasis was given in seeking out people who had the empirical knowledge on medicinal plants and experience in the use of traditional medicinal plants. Personally administered method was followed during the survey. Open-ended and semistructured questionnaire was used $[37,38]$ for this survey seeking for the following information: (a) the local name, (b) plants part/s used, (c) the method of preparation, (d) solvent/adjuvant used, (e) mode of application, (f) gastrointestinal and other medicinal uses, $(\mathrm{g})$ voucher specimen number, and $(\mathrm{h})$ dose and dosage forms. After completion of survey, consultation with Botanist Mr. Manzur-ul-Kadir Mia, M.D., Former Principal Scientific Officer and Consultant of Bangladesh National Herbarium, Dhaka, was carried out for getting identification, scientific names, family names, habit, habitat, nature, relative abundance, and preservation of the species. The voucher specimens of the plants were deposited in Bangladesh National Herbarium, Dhaka (DACB).

2.3. Data Analysis. All the species were listed in alphabetical order by their scientific name, family, local name, general name, plants parts used, mode of preparation, habit, habitat, relative abundance, nature, general name, solvent used, and frequency of citation (FC). Here FC is defined as the ratio of "number of times a particular species was mentioned" and "total number of times that all species were mentioned" multiplied by 100 . All the data such as frequency distributions were calculated by using SPSS 16.0.

\section{Results}

3.1. Informants. Among the 110 interviewees, major informants were male (65\%), aged (regardless of gender) 50-60 years $(31 \%)$, mostly with 5 years of institutional education (44\%), and having $10-20$ years of relevant experience (34\%) (Table 1).

\subsection{Plants Using in Treatment of Snakebite and Other Relevant} Information. 116 plant species belonging to 48 plant families have been identified as being used in the treatment of snakebite by traditional healers in Bangladesh. The largest number of species was noted from the family Fabaceae (10 species), followed by Apocynaceae (8 species), Caesalpiniaceae (7 species), and Euphorbiaceae (6 species) (Figure 2).

Leaves (43\%) were the most frequently used plant parts, followed by roots (27\%) and roots stem (9.4\%) (Figure 3). The major mode of preparation is paste $(69.3 \%)$ followed by juice $(21 \%)$ and powder (11.23\%). Preparations were made
TABLE 1: Demographic data of the informants.

\begin{tabular}{|c|c|c|c|}
\hline Variable & Categories & $\begin{array}{c}\text { Frequency } \\
(n=110)\end{array}$ & Percentage \\
\hline \multirow{2}{*}{ Gender } & Male & 72 & 65 \\
\hline & Female & 38 & 35 \\
\hline \multirow{5}{*}{ Age (years) } & $<30$ & 16 & 15 \\
\hline & $30-40$ & 25 & 23 \\
\hline & $40-50$ & 23 & 21 \\
\hline & $50-60$ & 34 & 31 \\
\hline & $>60$ & 12 & 11 \\
\hline \multirow{7}{*}{$\begin{array}{l}\text { Education } \\
\text { (years) }^{\dagger}\end{array}$} & $0^{*}$ & 20 & 18 \\
\hline & 5 & 48 & 44 \\
\hline & 8 & 21 & 19 \\
\hline & 10 & 15 & 14 \\
\hline & 12 & 12 & 11 \\
\hline & 16 & 10 & 10 \\
\hline & $>16$ & 4 & 4 \\
\hline \multirow{5}{*}{ Experience $^{\ddagger}$} & $<2$ & 18 & 16 \\
\hline & $2-5$ & 25 & 23 \\
\hline & $5-10$ & 18 & 16 \\
\hline & $10-20$ & 37 & 34 \\
\hline & $>20$ & 12 & 11 \\
\hline \multirow[t]{2}{*}{ Profession ${ }^{¥}$} & $\begin{array}{c}\text { Traditional health } \\
\text { practitioners }\end{array}$ & 42 & 38 \\
\hline & Indigenous people & 68 & 62 \\
\hline
\end{tabular}

${ }^{*}$ These people do not have any formal educational training; ${ }^{\dagger}$ year completed through formal educational institution; ${ }^{\ddagger}$ relevant to treating people; ${ }^{¥}$ people who acquired medicinal knowledge by themselves and are usually involved in profession not relevant to medicine.

with water, honey, wine, lime water, and milk as solvent. The mode of administration was oral (31.9\%), topical (56.03\%), and oral and topical (12.07\%) (Figure 4). 32\% of the reported species were herb which was followed by tree $(23.3 \%)$ and climber (9.5\%). Most of the plants are wild (70\%) and some are cultivated $(18 \%)$, whereas others are both cultivated and wild (Table 2). The species Rauvolfia serpentina, Allium cepa, Aristolochia indica, Costus speciosus, Emblica officinalis, Hemidesmus indicus, Leucas aspera, and Vitex negundo were the most frequently cited in study area. The doses of the available plants are presented in Table 3.

\section{Discussion}

Fabaceae is the most dominant family in the current investigation. This is perhaps because of worldwide prevalence of the species from this family $[112,113]$. Leaves were the major plant parts used solely or mixed with other parts in the treatment of snakebite. Ease of collection of leaves is the prime reason compared to roots, flowers, and fruits [114-116]. On the other hand, herbs and trees were the most common habit of the reported plants which might be attributed to the huge number of trees or herbaceous plants naturally abundant in this hilly area [117]. 


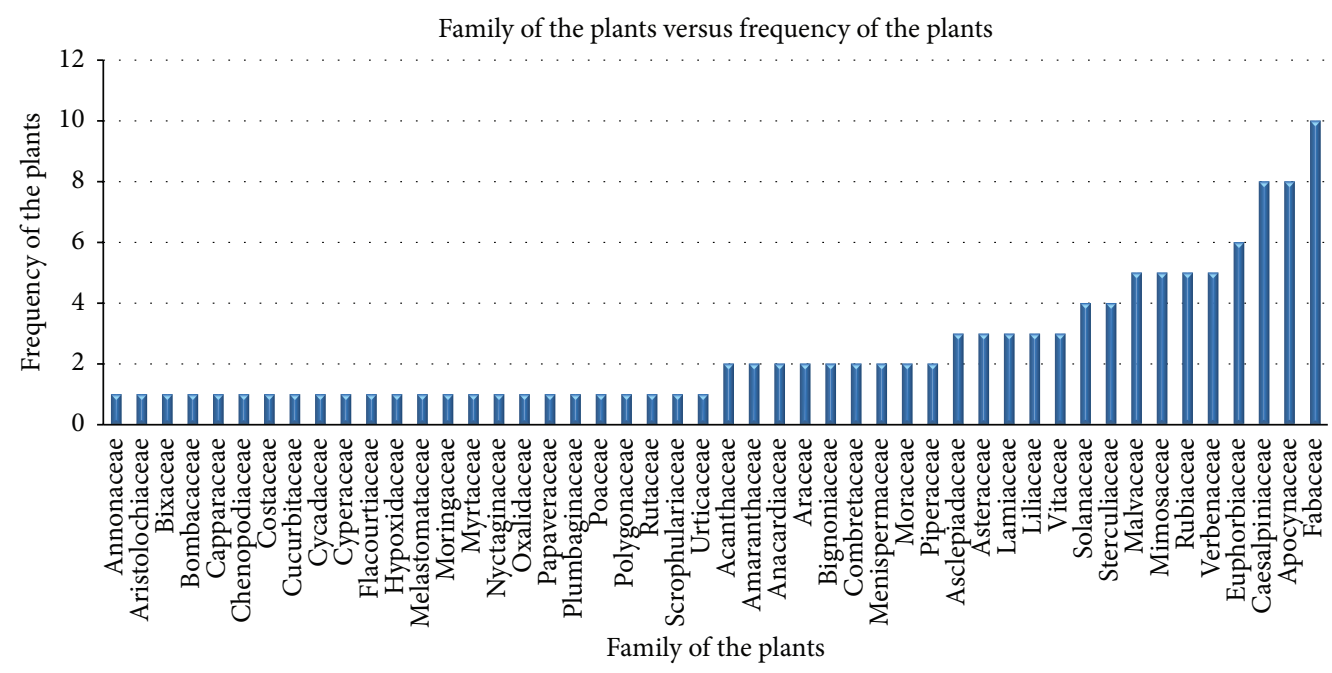

- Frequency of the plants

FIGURE 2: Family of the plants with their frequencies.

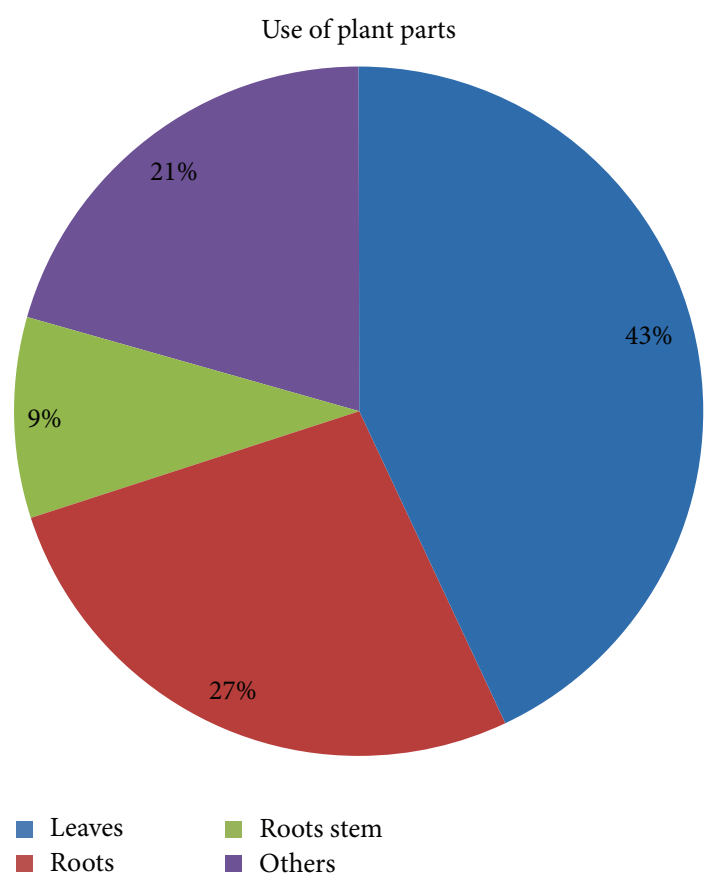

Figure 3: Percentage of plant parts used.

It was very common that blend of different adjuvant including other plant parts was used for the preparation of medication to counteract snake venom. Several researchers also reported this kind of polyherbal treatment [118-121]. The frequent use of multiple plant remedies might be illustrated by the phenomenon of synergistic actions where two or more plants produce an effect greater than the sum of their individual effects [122]. This is particularly true in case of medicinal plant treatment, since each medicinal plant contains numerous pharmacologically active compounds [118].

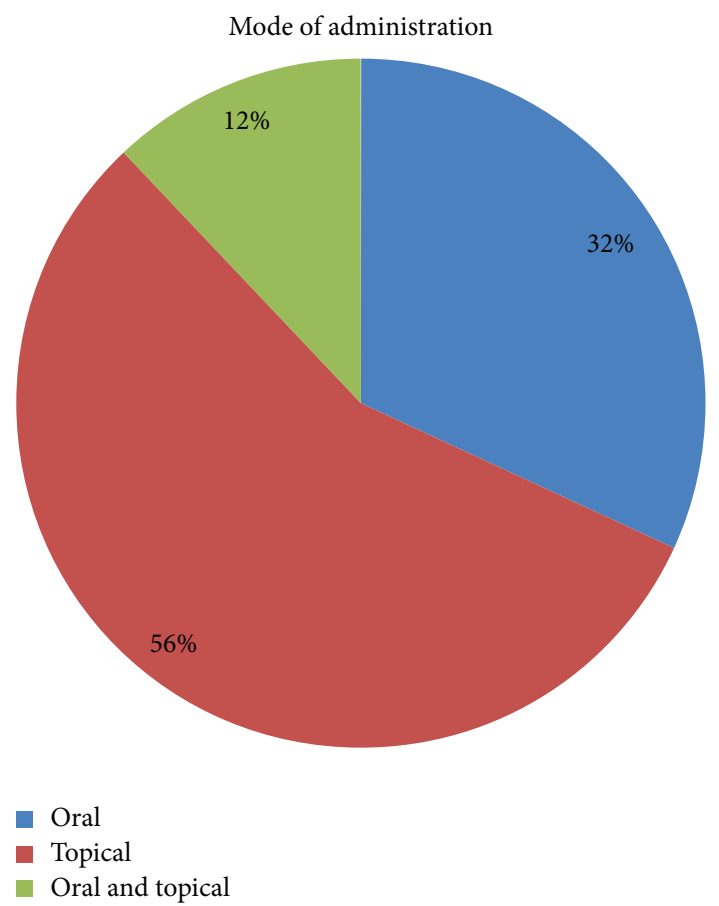

FIgURE 4: Percentage of mode of administration.

Among the management options after snakebite, snake charmers (Ozha in Bengali language) were the first contact following a snakebite for more than $80 \%$ of the victims in these areas [10]. We also noticed that the field of "snakes and snakebite" has a mythological fragrance in the mind of people living here. The Ozha not only depends on herbal remedies but also recites mantras (magical/mystical words) to enthrall people. There are also potentially harmful approaches reported few of which are making multiple incisions around the bite site, incorrect application techniques in 


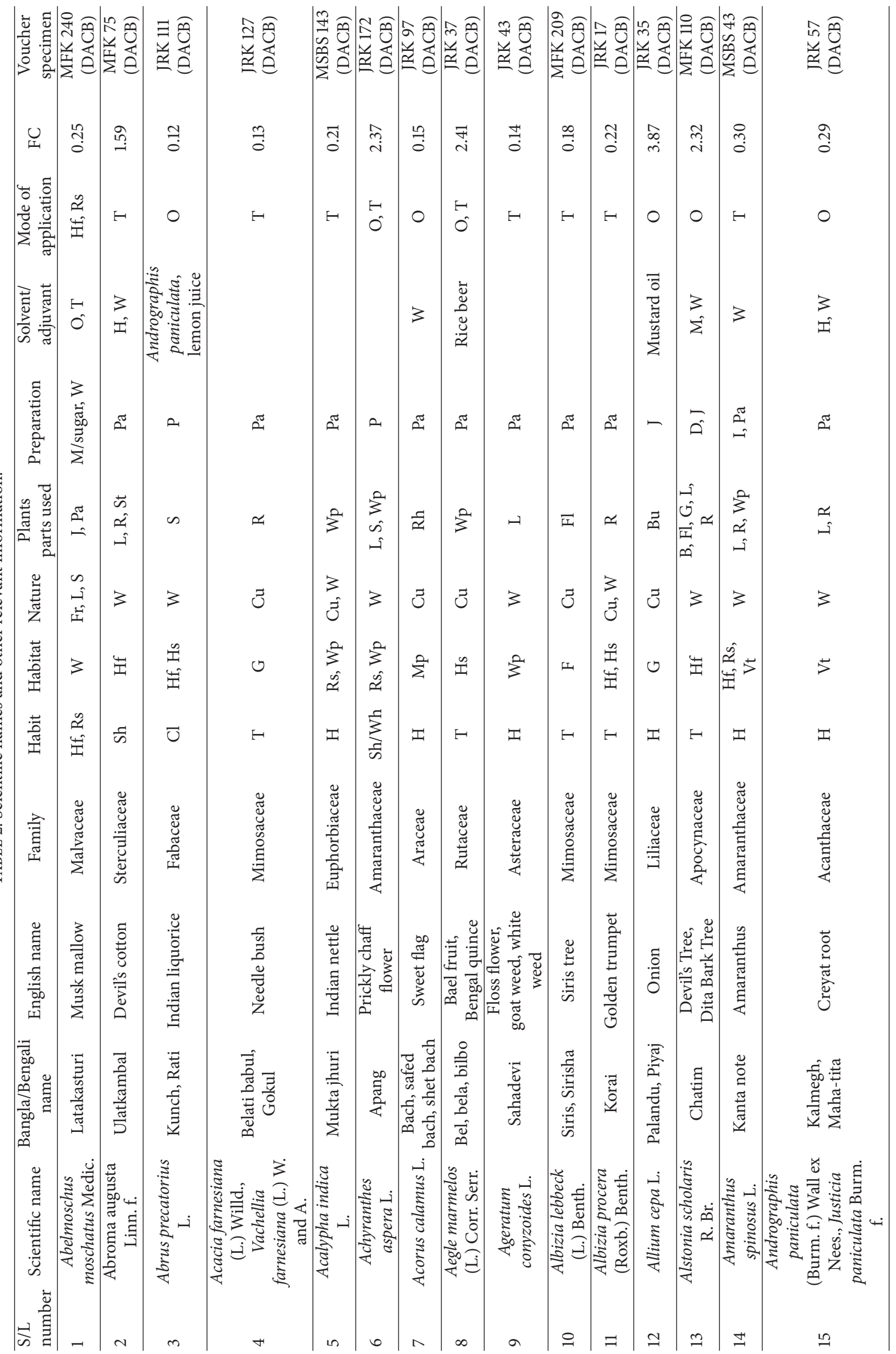




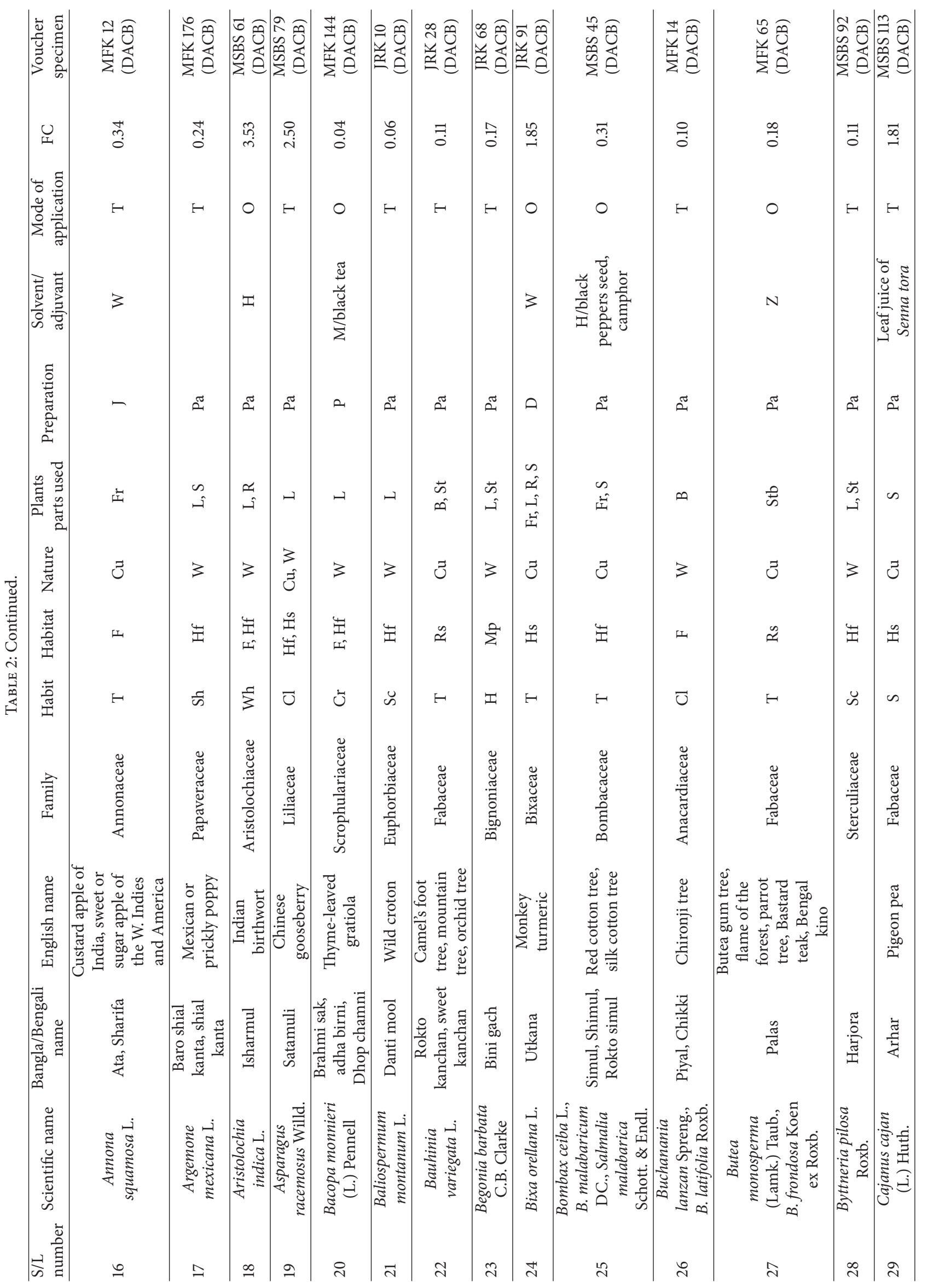




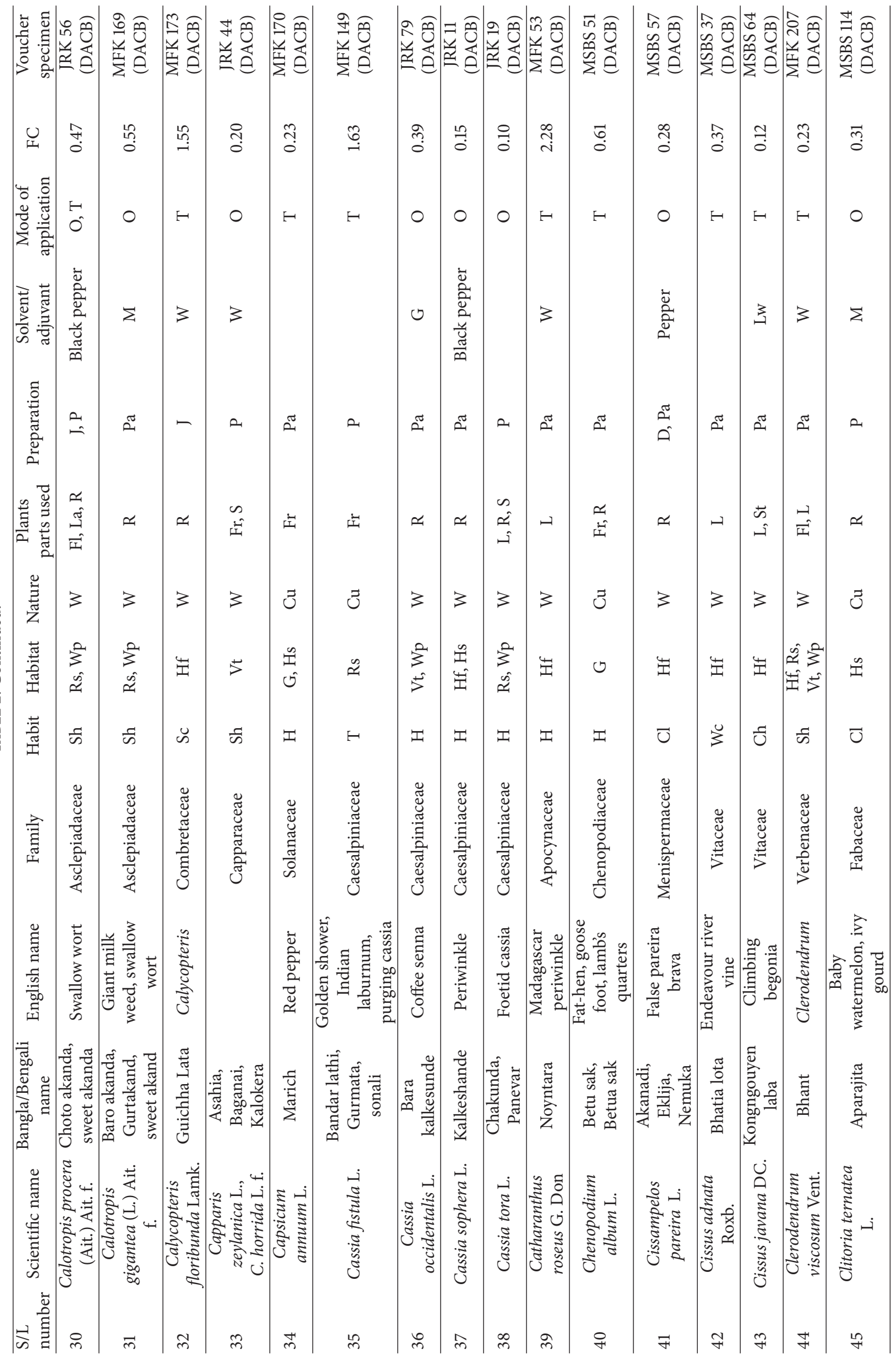




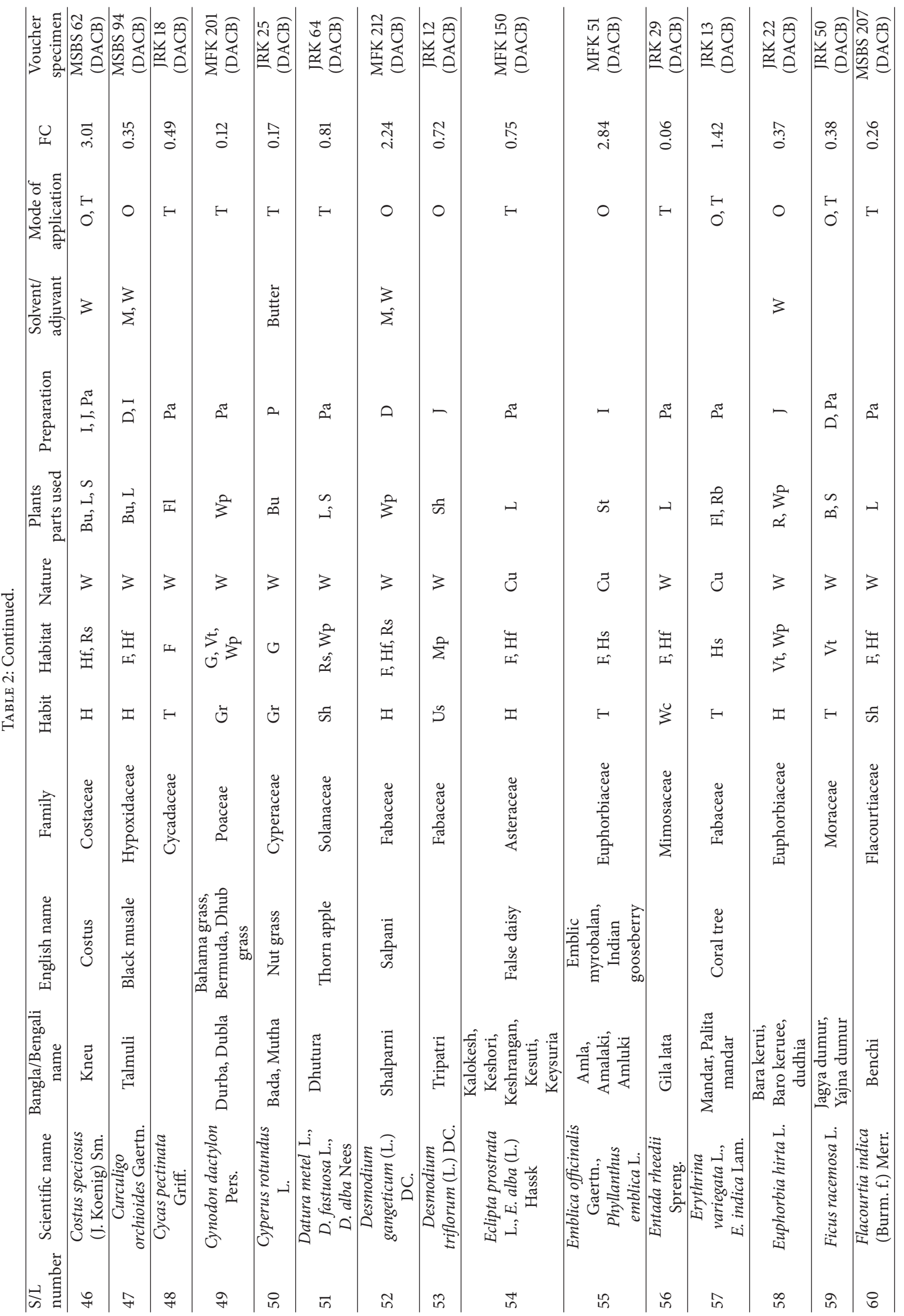




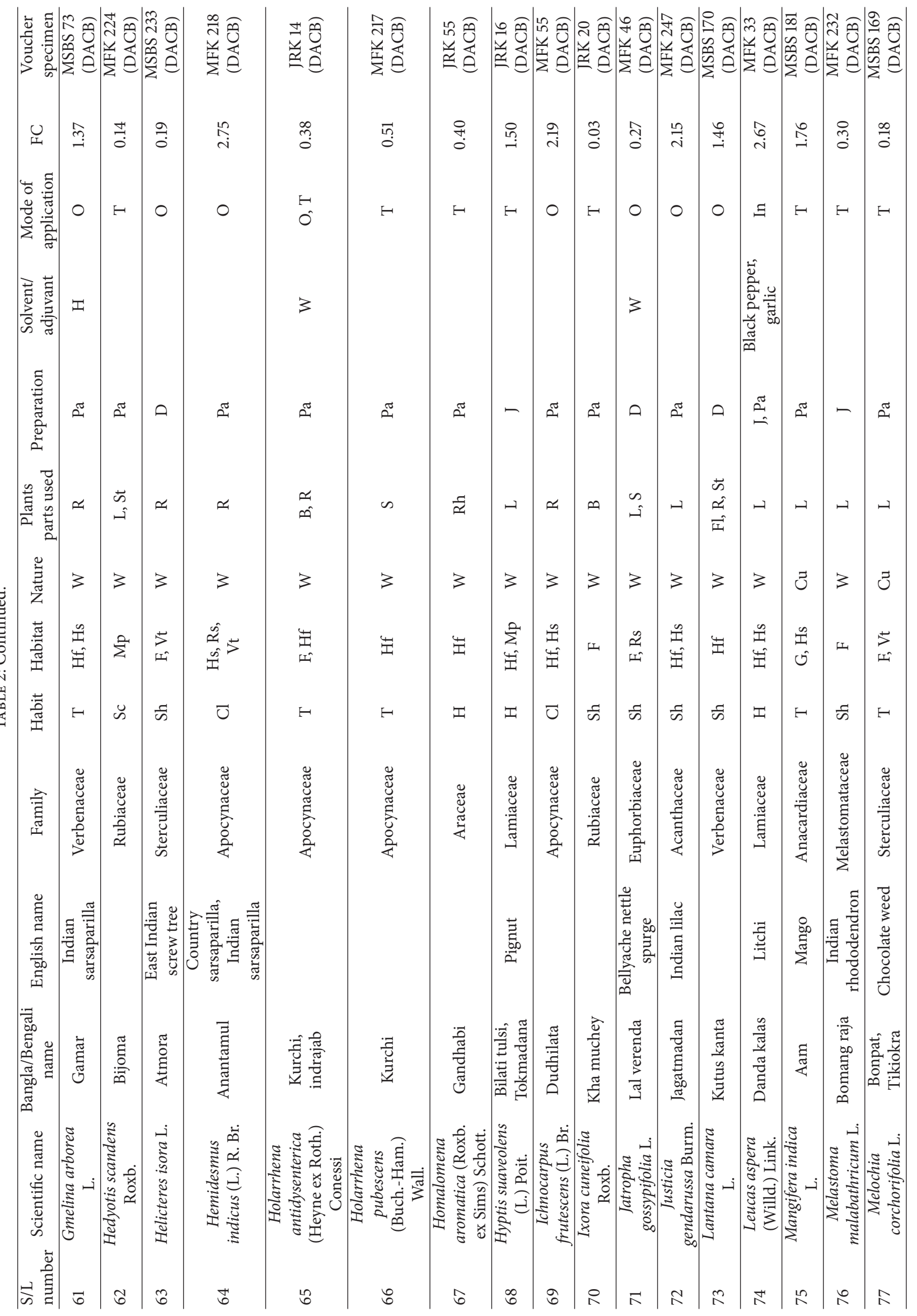




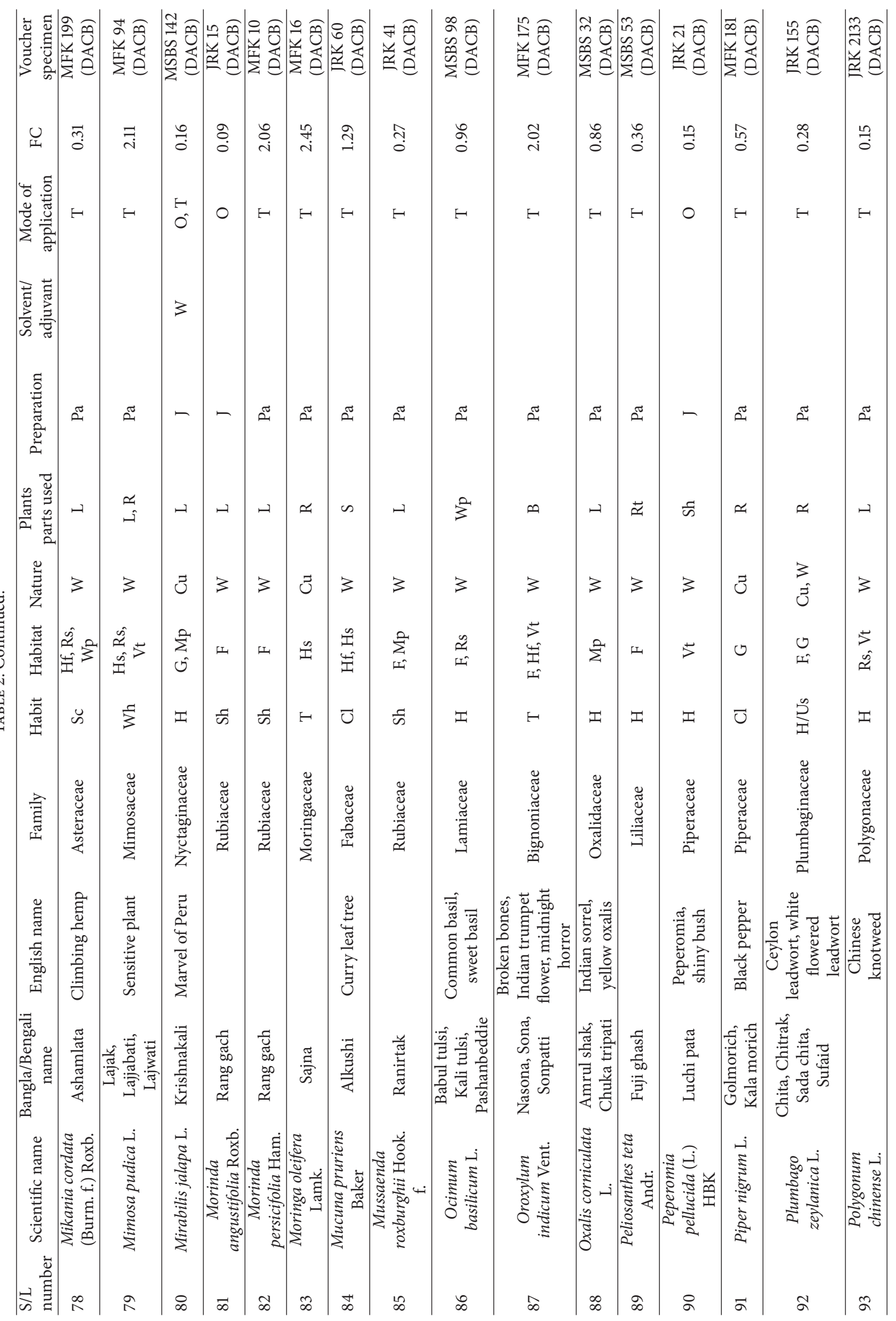




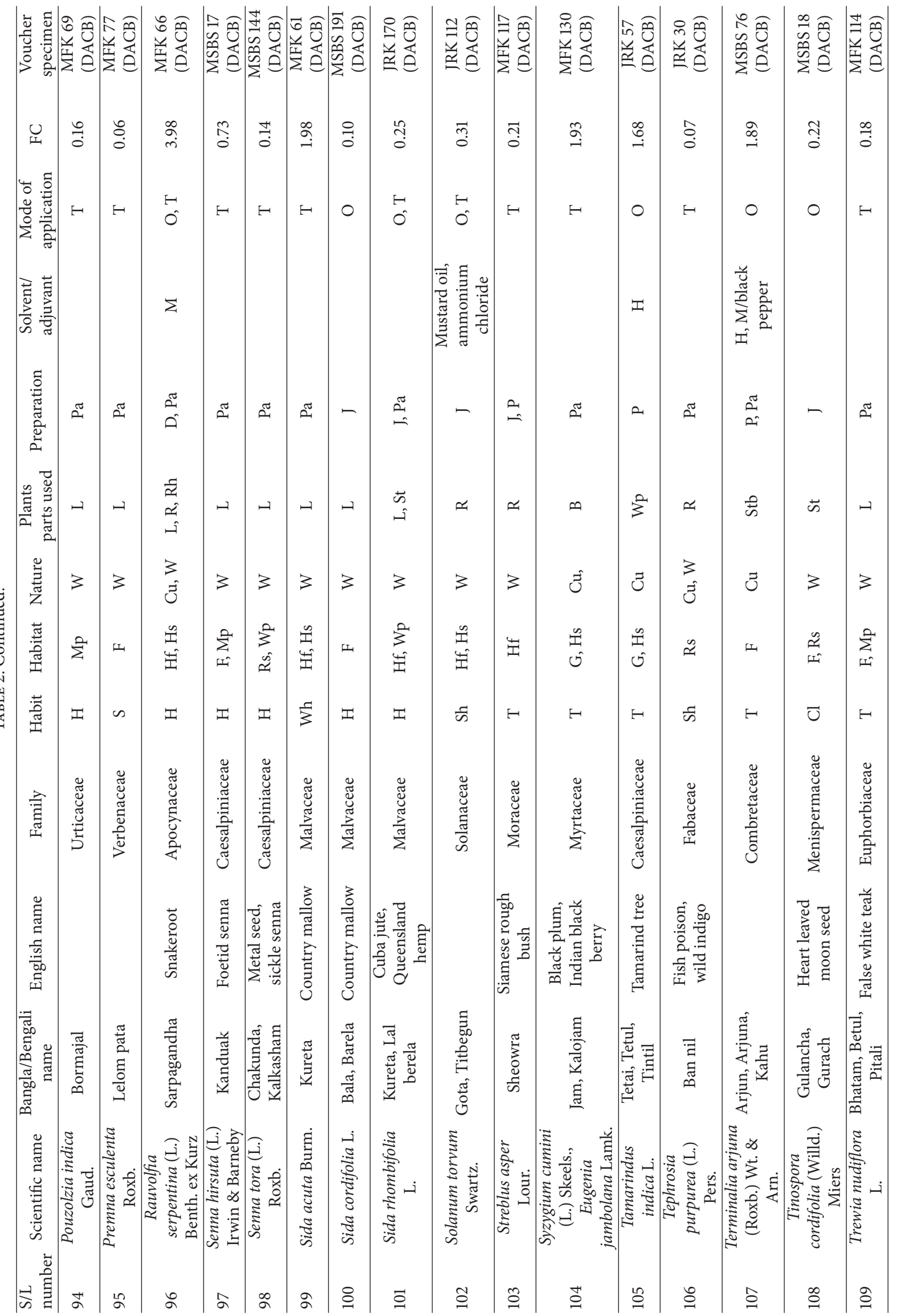




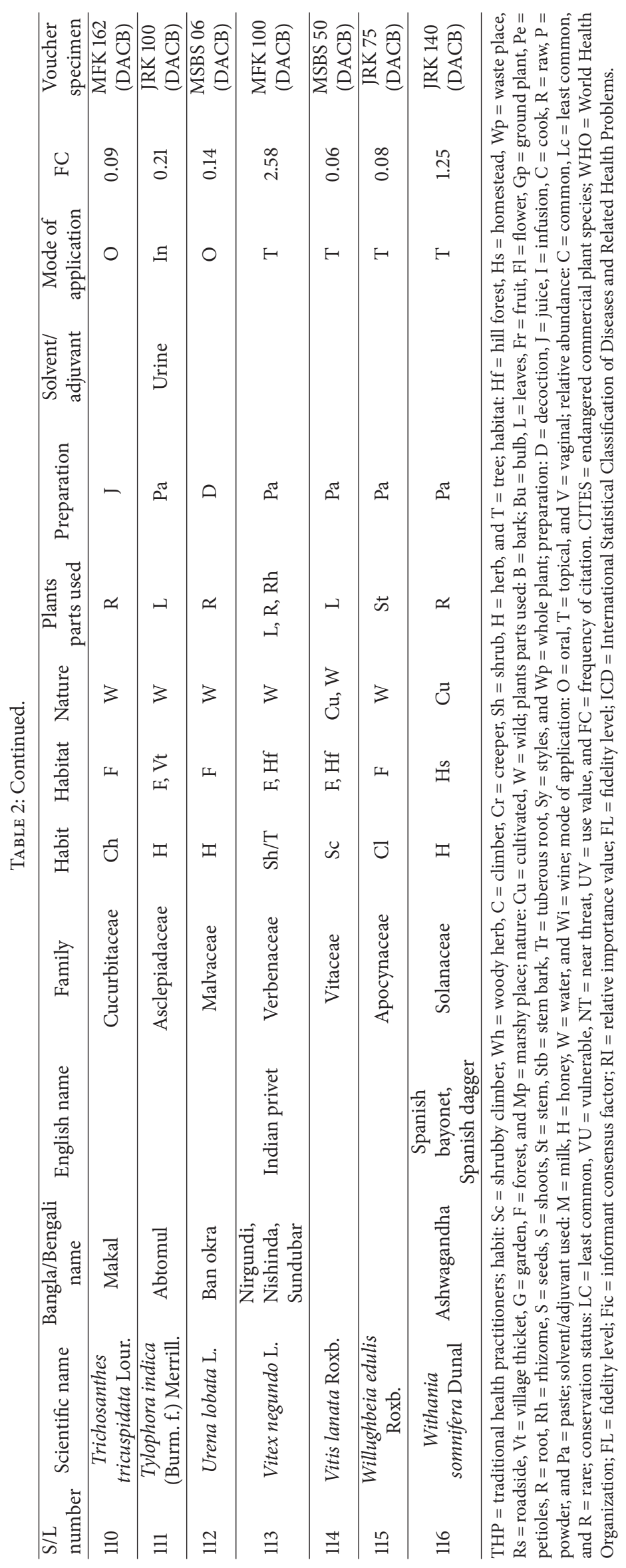


TABLE 3: Doses of the available plants.

\begin{tabular}{|c|c|c|}
\hline $\begin{array}{l}\mathrm{S} / \mathrm{L} \\
\text { number }\end{array}$ & Name of the plants & Doses \\
\hline 1 & $\begin{array}{l}\text { Abelmoschus moschatus } \\
\text { Medic. }\end{array}$ & $\begin{array}{l}\text { Paste of leaf, fruit, and seed is used on the infected area } 2 / 3 \text { times daily for } 2 / 3 \text { days. Juice of leaf, } \\
\text { fruit, and seed is also taken by grinding with milk and sugar. }\end{array}$ \\
\hline 2 & Abroma augusta Linn. f. & Root juice is used after maceration. \\
\hline 3 & Abrus precatorius L. & Seed powder is mixed with Andrographis paniculata seed powder to consume with lemon juice. \\
\hline 4 & $\begin{array}{l}\text { Acacia farnesiana (L.) } \\
\text { Willd. }\end{array}$ & 3-4 pieces of fresh root are crushed and squeezed; the extract is taken $3-5$ times a day for 1 day. \\
\hline 5 & Acalypha indica L. & $\begin{array}{l}\text { Whole plant is made into paste, and the paste thus obtained is divided into } 4-5 \text { equal parts; each } \\
\text { part is given at } 6 \text {-hour intervals as an antidote. }\end{array}$ \\
\hline 6 & Achyranthes aspera $\mathrm{L}$. & Fresh leaves extract of about 2 teaspoonfuls is given $4-6$ times a day. \\
\hline 7 & Acorus calamus L. & $\begin{array}{l}\text { Fresh rhizome is made into paste. The paste is given with a glass of lukewarm water twice a day for } \\
3 \text { successive days. }\end{array}$ \\
\hline 8 & $\begin{array}{l}\text { Aegle marmelos (L.) } \\
\quad \text { Corr. Serr. }\end{array}$ & $\begin{array}{l}\text { Whole plants, in tender condition, are made into paste. The paste thus obtained is divided into two } \\
\text { equal halves, one half mixed with rice beer applied for cleaning the biting site and the other half } \\
\text { again divided into } 6 \text { equal portions, and each part is given at an interval of } 4-6 \text { hours of time for } \\
\text { one day. }\end{array}$ \\
\hline 9 & $\begin{array}{l}\text { Albizia procera (Roxb.) } \\
\text { Benth. }\end{array}$ & $\begin{array}{l}\text { Fresh root of about one inch long, collected from the plants which are yet not flowered, is given } \\
\text { once as an antidote of snakebite. }\end{array}$ \\
\hline 10 & Allium cepa L. & $\begin{array}{l}\text { Two teaspoonfuls of bulb juice of the plant mixed with mustard oil and administered to expel } \\
\text { poison by vomiting. }\end{array}$ \\
\hline
\end{tabular}

(1) Fresh root and leaves are mixed in a ratio of $2: 3$ and the whole mixture is made into paste with a Andrographis paniculata little water. The paste thus obtained is divided into 12-16 equal parts (based on the condition of the 11 (Burm. f.) Wall. ex Nees patient) and each part is given at regular intervals of 1-2 hours for 2-3 days.

(Burm. f.) Wall. ex Nees (2) Root paste along with honey in equal parts is given 6-8 times a day as an antidote of snake venom.

12 Annona squamosa L. Incision of snakebite is washed with the juice of plants.

$\begin{array}{ll}\text { Aristolochia indica L. } & \text { (1) Fresh root extract mixed with equal amount of root extract of Rauvolfa } \\ \text { times a day. } & \text { (2) Root paste along with honey in equal parts is given 6-8 times a day. }\end{array}$

\begin{tabular}{ccc}
\hline 14 & $\begin{array}{c}\text { Asparagus racemosus } \\
\text { Willd. }\end{array}$ & Leaf extract is applied on the bitten area. \\
\hline 15 & $\begin{array}{c}\text { Bacopa monnieri (L.) } \\
\text { Pennell }\end{array}$ & $\begin{array}{c}\text { Dried plant (except the root portion) powder, about } 1 \text { teaspoonful, is given with a cup of warm goat } \\
\text { milk or black tea 2-3 times of day as an antidote of snakebite. }\end{array}$ \\
\hline $\begin{array}{c}\text { Baliospermum } \\
\text { montanum L. }\end{array}$ & Paste is prepared with leaf and applied externally twice a day for $4 / 5$ days. \\
\hline 17 & $\begin{array}{c}\text { Begonia barbata C.B. } \\
\text { Clarke }\end{array}$ & Paste is prepared with stem and leaves and applied once a day for $2 / 3$ days. \\
\hline
\end{tabular}
18 Bombax ceiba L. pinch of camphor (Karpur); the paste thus obtained is given after mixing with a spoonful of honey as an antidote of snake venom.

\begin{tabular}{|c|c|c|}
\hline 19 & $\begin{array}{l}\text { Butea monosperma } \\
\text { (Lamk.) Taub. }\end{array}$ & $\begin{array}{l}\text { Stem bark (fresh or dried) about } 20 \mathrm{~g} \text { is made into paste with zinger (rhizome of Zingiber officinale). } \\
\text { The whole paste thus obtained is divided into four equal parts. Each of these } 4 \text { parts is given } 4 \text { times } \\
\text { a day. }\end{array}$ \\
\hline 20 & Byttneria pilosa Roxb. & Paste of stem and leaf is applied twice a day until the area is cured. \\
\hline 21 & Cajanus cajan (L.) Huth. & $\begin{array}{l}\text { Paste is made with seed powder of the plant and the juice of leaf of Senna tora. It is then applied } \\
\text { twice a day for } 2 / 3 \text { days. }\end{array}$ \\
\hline 22 & $\begin{array}{l}\text { Calotropis gigantea (L.) } \\
\text { Ait. f. }\end{array}$ & Fresh root with milk of cow is ground to a fine paste and taken as an antidote for snakebite. \\
\hline 23 & $\begin{array}{l}\text { Calotropis procera (Ait.) } \\
\text { Ait. f. }\end{array}$ & $\begin{array}{l}\text { About three drops of latex are put on the snake-bitten area and pressed downwards to bleed; root } \\
\text { extract is given two cups a day; flower powder is mixed with black pepper and taken. }\end{array}$ \\
\hline 24 & $\begin{array}{l}\text { Calycopteris floribunda } \\
\text { Lamk. }\end{array}$ & Root juice is used in infected area. \\
\hline 25 & Capparis zeylanica L. & $\begin{array}{l}\text { Dried fruits with seeds are made into dust; this dust is given as } 1 \text { teaspoonful with a glass of } \\
\text { lukewarm water as a snake venom antidote. }\end{array}$ \\
\hline
\end{tabular}


TABle 3: Continued.

\begin{tabular}{|c|c|c|}
\hline $\begin{array}{l}\text { S/L } \\
\text { number }\end{array}$ & Name of the plants & Doses \\
\hline 26 & Cassia fistula $\mathrm{L}$. & As a remedy against snakebite, one teaspoonful fruit powder is taken internally. \\
\hline 27 & Cassia occidentalis $\mathrm{L}$. & $\begin{array}{l}\text { 20-30 gm of root (fresh or dried) is made into paste with 3-4 pieces of "garlic" (Allium sativum) } \\
\text { and a little "gur" (Jaggery); the whole mixture thus obtained is given as an antidote to snakebite. }\end{array}$ \\
\hline 28 & Cassia sophera L. & $\begin{array}{l}\text { Root (fresh or dried) of about } 20 \text { gm is made into paste with 5-7 pieces of black peepers (seeds of } \\
\text { Piper nigrum) and the paste is given as an antidote. }\end{array}$ \\
\hline 29 & $\begin{array}{l}\text { Catharanthus roseus D. } \\
\text { Don }\end{array}$ & Leaf is grinded after maceration. \\
\hline 30 & Cissampelos pareira $\mathrm{L}$. & Root paste with $10 \mathrm{~g}$ long pepper is prescribed once daily for 5 days. \\
\hline 31 & Cissus adnata Roxb. & Leaf paste is applied on infected place. \\
\hline 32 & Cissus javana DC. & $\begin{array}{l}\text { Paste is made with leaf and stem, mixing with lime, and applied externally on the biting place tying } \\
\text { a piece of cloth for } 3 / 4 \text { days. }\end{array}$ \\
\hline 33 & Clitoria ternatea $\mathrm{L}$. & Root powder mixed with milk is taken orally immediately after snakebite. \\
\hline 34 & Cycas pectinata Griff. & Paste of flower is applied thrice a day for $2 / 3$ days. \\
\hline 35 & Cyperus rotundus $\mathrm{L}$. & Bulb powder mixed with cow butter to treat snakebite. \\
\hline 36 & $\begin{array}{l}\text { Desmodium triflorum } \\
\text { (L.) DC. }\end{array}$ & $\begin{array}{l}\text { Juice is prepared with shoots and mixing with shoots of Peperomia pellucida and } 2 \text { spoonfuls are } \\
\text { taken thrice a day for } 4 / 5 \text { days. }\end{array}$ \\
\hline 37 & $\begin{array}{l}\text { Emblica officinalis } \\
\text { Gaertn. }\end{array}$ & Stem infusion is given orally as an antidote. \\
\hline 38 & Entada rheedii Spreng. & Paste is prepared with leaf and applied externally once a day for $4 / 5$ days. \\
\hline 39 & Erythrina variegata $\mathrm{L}$. & $\begin{array}{l}\text { Stamen and root bark are mixed in a ratio of } 1: 3 \text { and then they are made into paste. This paste is } \\
\text { applied in both ways externally and internally to reduce the swelling, pain of snakebite. }\end{array}$ \\
\hline 40 & Ficus racemosa $\mathrm{L}$. & $\begin{array}{l}\text { A few drops of its decoction are put into the nostrils, resulting into vomiting and relief; bark paste } \\
\text { is applied over the injury. }\end{array}$ \\
\hline 41 & Gmelina arborea $\mathrm{L}$. & $\begin{array}{l}\text { Inner portion of fresh root (after peeling off the bark) about } 20 \mathrm{~g} \text { is made into paste and this paste is } \\
\text { given with a spoonful of honey as an antidote of snakebite. }\end{array}$ \\
\hline 42 & Hedyotis scandens Roxb. & $\begin{array}{l}\text { Paste is prepared with leaf and stem and applied in warmed condition externally twice a day for } 3 / 4 \\
\text { days. }\end{array}$ \\
\hline 43 & $\begin{array}{l}\text { Hemidesmus indicus (L.) } \\
\text { R. Br. }\end{array}$ & Root paste is applied as an antidote to snakebite. \\
\hline 44 & $\begin{array}{c}\text { Holarrhena } \\
\text { antidysenterica (Heyne } \\
\text { ex Roth.) Conessi }\end{array}$ & $\begin{array}{l}\text { The roots were rubbed on a stone with a few drops of water and the paste obtained is given } \\
\text { internally and applied externally in snakebite. }\end{array}$ \\
\hline 45 & $\begin{array}{l}\text { Holarrhena pubescens } \\
\text { (Bach.-Ham.) Wall. }\end{array}$ & Seed paste is applied locally as antidote and also for reducing the swelling and pain of snakebite. \\
\hline 46 & $\begin{array}{l}\text { Homalomena aromatica } \\
\text { (Roxb. ex Sims) Schott. }\end{array}$ & Paste of rhizomes is applied until the area is cured. \\
\hline 47 & $\begin{array}{l}\text { Hyptis suaveolens (L.) } \\
\text { Poit. }\end{array}$ & Juice is extracted from leaf and applied externally twice a day for 3 days. \\
\hline 48 & $\begin{array}{l}\text { Ichnocarpus frutescens } \\
\text { (L.) Br. }\end{array}$ & $\begin{array}{l}\text { Fresh roots (about } 100 \mathrm{~g} \text { ) are crushed and squeezed; the aqueous extract thus obtained is given } \\
10-12 \text { times a day as an antidote. }\end{array}$ \\
\hline 49 & Ixora cuneifolia Roxb. & Bark is grinded with water and the paste applied on the biting area twice a day for $4 / 5$ days. \\
\hline 50 & $\begin{array}{l}\text { Justicia gendarussa } \\
\text { Burm. }\end{array}$ & $\begin{array}{l}\text { Fresh leaves extract is given } 20-30 \mathrm{~mL} \text { at every 1-hour interval for up to } 18 \text { hours of snakebite as an } \\
\text { antidote. }\end{array}$ \\
\hline 51 & Lantana camara L. & Decoction of roots, flowers, and stems is prescribed. \\
\hline 52 & $\begin{array}{l}\text { Leucas aspera (Willd.) } \\
\text { Link. }\end{array}$ & Leaves with pepper and garlic are chewed and spit into the nostrils. \\
\hline 53 & $\begin{array}{l}\text { Melastoma } \\
\text { malabathricum L. }\end{array}$ & Juice is prepared with leaf and applied externally twice a day for $3 / 4$ days. \\
\hline 54 & Melochia corchorifolia L. & Leaf paste is applied on infected place. \\
\hline 55 & Mirabilis jalapa L. & $\begin{array}{l}\text { Leaf juice is extracted and } 2 \text { spoonfuls are taken twice a day for } 2 / 3 \text { days. Also it is applied topically } \\
\text { twice a day in infected areas. }\end{array}$ \\
\hline
\end{tabular}


TABLe 3: Continued.

\begin{tabular}{|c|c|c|}
\hline $\begin{array}{l}\text { S/L } \\
\text { number }\end{array}$ & Name of the plants & Doses \\
\hline 56 & $\begin{array}{l}\text { Morinda angustifolia } \\
\text { Roxb. }\end{array}$ & 4 spoonfuls of extracted leaf juice are taken thrice a day until the area is cured. \\
\hline 57 & $\begin{array}{l}\text { Morinda persicifolia } \\
\text { Ham. }\end{array}$ & Paste is prepared with leaf and applied externally twice a day for $3 / 4$ days. \\
\hline 58 & $\begin{array}{l}\text { Mussaenda roxburghii } \\
\text { Hook. f. }\end{array}$ & Paste of leaf is applied on the infected place with tying a piece of cloth. \\
\hline 59 & Peliosanthes teta Andr. & Paste is prepared with root tuber and applied externally once a day for 2 days. \\
\hline 60 & $\begin{array}{l}\text { Peperomia pellucida (L.) } \\
\text { HBK }\end{array}$ & $\begin{array}{l}\text { Juice is prepared with shoots and mixing with shoots of Desmodium triflorum and } 2 \text { spoonfuls are } \\
\text { taken thrice a day for } 4 / 5 \text { days. }\end{array}$ \\
\hline 61 & Polygonum chinense L. & Paste is prepared with leaf and applied externally once a day for 2 days. \\
\hline 62 & Pouzolzia indica Gaud. & Paste of leaves is applied twice a day for $2 / 3$ days. \\
\hline 63 & Premna esculenta Roxb. & Paste is prepared with leaf and applied externally twice a day for $3 / 4$ days. \\
\hline 64 & $\begin{array}{l}\text { Rauvolfia serpentina (L.) } \\
\text { Benth. ex Kurz }\end{array}$ & $\begin{array}{l}\text { Roots and leaf buds are crushed with milk and made into a paste and used internally and externally } \\
\text { on the affected area; rhizome and root decoction is given orally. }\end{array}$ \\
\hline 65 & $\begin{array}{l}\text { Senna hirsuta (L.) Irwin } \\
\text { \& Barneby }\end{array}$ & Paste of leaf is applied topically on the biting place. \\
\hline 66 & Senna tora (L.) Roxb. & Paste is prepared with leaf and applied once a day for $2 / 3$ days. \\
\hline 67 & Sida cordifolia L. & Leaf juice is applied to cure snakebite. \\
\hline 68 & Sida rhombifolia $\mathrm{L}$. & $\begin{array}{l}\text { Paste is prepared with leaf and stem and applied topically once a day to infected areas. Also juice of } \\
\text { extracted leaf and stem is } 2 \text { spoonfuls which are taken four times a day for } 4 / 5 \text { days. }\end{array}$ \\
\hline 69 & Solanum torvum Swartz. & $\begin{array}{l}\text { Root juice is mixed with } 250 \mathrm{~mL} \text { water and } 100 \mathrm{~mL} \text { mustard oil. First, ammonium chloride is } \\
\text { rubbed on the snake-bitten area and then the mixture of root juice, water, and oil is given orally. } \\
\text { Otherwise, } 1 \text { handful of fruit is boiled in } 1 / 2 \text { litre of water. The fruits are then squeezed to get the } \\
\text { juice, which is orally given to the snake-bitten person to vomit out the poison. }\end{array}$ \\
\hline 70 & Tamarindus indica $\mathrm{L}$. & To treat snakebite, spoonful powder with honey is consumed thrice a day after every two hours. \\
\hline 71 & $\begin{array}{l}\text { Terminalia arjuna } \\
\text { (Roxb.) Wt. \& Arn. }\end{array}$ & $\begin{array}{l}\text { Stem bark powder (about } 10 \mathrm{~g} \text { ) is made into paste with a teaspoon full of honey and 5-7 pieces of } \\
\text { black pepper (Piper nigrum); this paste is given with a glass of lukewarm goat milk as an antidote to } \\
\text { snake venom. }\end{array}$ \\
\hline 72 & $\begin{array}{l}\text { Tinospora cordifolia } \\
\text { (Willd.) Miers }\end{array}$ & Stem juice is used to cure snakebite. \\
\hline 73 & Trewia nudiflora L. & Paste of leaf is applied topically on the biting place. \\
\hline 74 & $\begin{array}{l}\text { Trichosanthes } \\
\text { tricuspidata Lour. }\end{array}$ & Root juice is prepared after maceration and 1 spoonful is taken twice a day until the area is cured. \\
\hline 75 & $\begin{array}{l}\text { Tylophora indica (Burm. } \\
\text { f.) Merrill. }\end{array}$ & $\begin{array}{l}\text { Handful of leaves is crushed in urine of snake-bitten person and 2-3 drops of extract are passed } \\
\text { through the nostrils. }\end{array}$ \\
\hline 76 & Urena lobata L. & $\begin{array}{l}\text { Decoction of root along with leaves of Adhatoda vasica, Alangium salvifolium, and Cocciniagrandis } \\
\text { is taken internally. }\end{array}$ \\
\hline 77 & Vitis lanata Roxb. & Paste is prepared with leaf and applied externally once a day for $3 / 4$ days. \\
\hline 78 & Willughbeia edulis Roxb. & Latex is collected from stem and applied externally thrice a day for $2 / 3$ days. \\
\hline
\end{tabular}

tourniquets (e.g., wrong pressure), and sucking blood orally from the multiple cuts which are practiced in an alarmingly high proportion of cases.

The species with high FC values is a sign of their diverse and numerous medicinal activities and thus it offers further pharmacological, toxicological, and phytochemical analysis for the discovery of potential novel drugs.

Snake venom contains a complex mixture of enzymes, nonenzymatic proteins, carbohydrates, lipids, and other substances [123-126] most of which are extremely toxic. Snakebite envenoming has cytotoxic, hypotensive, neurotoxic, or anticoagulant effects [127]. Cytotoxic enzymes, phospholipases $\mathrm{A}_{2}$ and metalloproteinases, activate proinflammatory mechanisms that result in edema, blister formation, and local tissue necrosis and facilitate the release of bradykinin, prostaglandin, cytokines, and sympathomimetic amines that cause the intense pain [128]. In addition, there are some venom toxins including aminopeptidases having the ability to alter the physiological function of the victims and ultimately causing systemic hypotension [126]. Many snake venoms have peptides that inhibit angiotensin-converting enzyme causing a slump in arterial blood pressure [129]. Moreover, some toxins such as safarotoxins and endothelins are potent vasoconstrictors of coronary arteries and might be 
responsible for myocardial ischemia or cardiac arrhythmias [123]. Neurotoxins cause paralysis by affecting the neuromuscular transmission at either presynaptic or postsynaptic levels [130]. Presynaptic neurotoxins, also called b-neurotoxins, include taipoxin, paradoxin, trimucrotoxin, viperotoxin, Pseudocerastes, textilotoxin, and crotoxin [127] which are phospholipase $\mathrm{A}_{2}$ complexes that inhibit the release of acetylcholine from the presynaptic terminal $[131,132]$. On the other hand, postsynaptic neurotoxins including irditoxin [127] called a-neurotoxins cause a reversible blockage of acetylcholine receptors [133-135]. Snake venom toxins may also interfere with blood coagulation and cause hemorrhages or thrombosis [125, 127, 136, 137].

Elucidation of the mode of actions of 116 plants individually is beyond the scope of this study. Research suggests extract of different medicinal plants having antivenom activities such as reducing necrotic and hemorrhagic activity as well as preventing cardiac arrest and reversing the effect of paralysis of skeletal muscle caused by snake venom. Also they might inhibit phospholipase $\mathrm{A}_{2}$ that causes degranulation of mast cell [138] and consequently they prevent release of platelet activating factors and histamine into circulation, preventing hypersensitive anaphylactic reaction [139].

Several studies have been conveyed in finding of active constituents in the plants used against snake venom. Among the 116 plants in this study, the phytochemical investigations are conducted in most of the plants though the compounds rational for antivenom properties are still unknown for most of them. Extensive phytochemical investigations on the plants mentioned in this study could be another mammoth task. Several plant constituents like flavonoids, quinonoid, xanthene, polyphenols, terpenoids lupeol, gymnemagenin, and pentacyclic triterpenes like oleanolic acid, ursolic, tannins, taraxasterol, amyrin, and so forth are found to be present in varying proportions in surveyed plants. These compounds have also been previously tested in vitro for possessing protein binding and enzyme inhibiting properties [140-142].

These literature studies revealed that the alkaloids (Eclipta prostrate, Rauvolfia serpentina, Strychnos nux-vomica, and Mimosa pudica), esters (Gloriosa superba), phenolic fraction (Hemidesmus indicus), terpenoids (Aristolochia indica, Andrographis paniculata), and flavonoids fraction (Tephrosia purpurea) neutralized the snake venom activities. Flavonoids have been shown to inhibit phospholipases $\mathrm{A}_{2}$, an important component of snake venoms [143]. The antivenom effects of wedelolactone, a coumestan isolated from the Eclipta prostrate, are well cited for antivenom activities [144]. 2-Hydroxy4-methoxy benzoic acid, found in Hemidesmus indicus root extracts, was identified as a snake venom neutralizing factor which effectively neutralized viper venom induced lethal, hemorrhagic, coagulant, anticoagulant, and inflammatory activity [145]. This compound seems to act through free radical formation system [146] and is one of the mechanisms of venom inhibition. Caffeic acid is present in Strychnos nuxvomica, and the monomeric caffeic acid is a proven antidote against snake venoms when given as oral and parenteral administration [147]. Marmin in Aegle marmelos, a monoterpenoid substituted fernolin [148], has been mentioned as a remedy against snakebite. Piperine from Piper nigrum inhibits the adhesion of neutrophils to endothelial monolayers. Also it possesses inhibitory activities on prostaglandin and leukotrienes and thus possesses anti-inflammatory activity [149-151]. Quercetin is a potent inhibitor of lipoxygenase, and free quercetin and its glycosides rutin are present in Allium cepa skins [152]. The aristolochic acid content of Aristolochia indica contains a large number of proteins that cluster under native condition. It shows strong gelatinolytic, collagenase, nuclease, and peroxidase activities. It interacts with the components of snake venom and partially inhibits proteolytic and L-amino acid oxidase activities of the venom [12]. Active principle of Bauhinia forficata has thrombin-like enzyme that acts as potent inhibitor of clotting activity that otherwise causes persistent hemorrhage [153].

Most of the plants documented in this study are used for the treatment of versatility of disease. This trend is a possible indication of the tradition of THPs to develop local healing system through trials and errors for optimal treatment practices [154].

There are resemblances in comparative studies of these cited plants to other surveys regarding medicinal plants having antivenin characteristics (Table 4). Using the same plants in different areas by different cultures for the same purpose might be considered as a justification of their pharmacological efficacy [155].

12 of these cited plants had been found to possess possible toxic potentiality (Table 5). However, among those possibly the most toxic one is Abrus precatorius. It contains abrin, a serious toxic compound, which after penetrating the cells of the body inhibits cell protein synthesis. Human fatal dose of abrin is approximately $0.1-1 \mathrm{mg} / \mathrm{kg}$. But toxins are released only if the seed is chewed and swallowed [91]. Another dangerous plant is Ageratum conyzoides which in ingestion can cause liver lesions and tumors [94, 95]. There was a mass poisoning incident reported in Ethiopia as a result of contamination of grain with $A$. conyzoides [96]. In addition, epidemic dropsy and ocular toxicity have been reported by seed oil of Argemone mexicana [98-101] and latex of Calotropis procera [105], respectively; the rest are toxic only due to high doses of ingestion. However, a number of phytochemical investigations would be required to declare these plants as being toxic.

\section{Conclusion}

This survey represents the contribution of natural flora of Bangladesh to the global approach in the management of snakebite occurrences. The knowledge documented in this study possibly supports the development of novel plant based treatment. Further investigations should be carried on especially in order to ensure safe therapy concerning medicinal plants. Therefore, snake charmers should be trained on as a priority basis. Again, scarcity of supply of snake antivenin is a major factor which needs to be addressed by local production. And in that case these findings regarding herbal antidote would be useful in planning and formulating strategies and specific interventions to combat snakebite related health problems in Bangladesh. 
TABLE 4: Worldwide comparative studies of cited plants of our survey.

\begin{tabular}{|c|c|c|c|}
\hline $\begin{array}{l}\text { Serial } \\
\text { number }\end{array}$ & Scientific name of the plant & Region/country & Reference(s) \\
\hline 1 & Abelmoschus moschatus Medic. & West Bengal, India & {$[39,40]$} \\
\hline 2 & Abrus precatorius $\mathrm{L}$. & Arunachal Pradesh, India & {$[41]$} \\
\hline 3 & Acacia farnesiana (L.) Willd. & West Bengal, India; Brazil & {$[42,43]$} \\
\hline 4 & Acalypha indica $\mathrm{L}$. & West Bengal, India & {$[44]$} \\
\hline 5 & Achyranthes aspera $\mathrm{L}$. & West Bengal, India & {$[39,43,44]$} \\
\hline 6 & Ageratum conyzoides $\mathrm{L}$. & Meghalaya, India & {$[45]$} \\
\hline 7 & Albizia lebbeck (L.) Benth. & Uttar Pradesh, India; Islamabad, Lahore, Pakistan & {$[46-48]$} \\
\hline 8 & Albizia procera (Roxb.) Benth. & West Bengal, India & {$[49]$} \\
\hline 9 & Allium cepa L. & Rajasthan, India; Brazil; Kenya & {$[33,43,50]$} \\
\hline 10 & Andrographis paniculata (Burm. f.) Wall. ex Nees & West Bengal, India & {$[44]$} \\
\hline 11 & Annona squamosa $\mathrm{L}$. & Nicobar, India & [51] \\
\hline 12 & Argemone mexicana L. & Rajasthan, India; Brazil & {$[43,52]$} \\
\hline 13 & Aristolochia indica L. & $\begin{array}{l}\text { Karnataka, Madhya Pradesh, Orissa, Tamil Nadu, } \\
\text { West Bengal, India }\end{array}$ & [53-57] \\
\hline 14 & Asparagus racemosus Willd. & Karnataka, India & {$[58]$} \\
\hline 15 & Bacopa monnieri (L.) Pennell & West Bengal, India & [59] \\
\hline 16 & Bauhinia variegata $\mathrm{L}$. & Rupandehi District, Nepal; Islamabad, Pakistan & {$[47,60,61]$} \\
\hline 17 & Bixa orellana L. & West Bengal, India & {$[59]$} \\
\hline 18 & Bombax ceiba L. & West Bengal, India & {$[49]$} \\
\hline 19 & Buchanania lanzan Spreng. & Tamil Nadu, Uttar Pradesh, India & {$[48,62]$} \\
\hline 20 & Butea monosperma (Lamk.) Taub. & West Bengal, India & {$[49]$} \\
\hline 21 & Calotropis procera (Ait.) Ait. f. & Rajasthan, Tamil Nadu, India; Balochistan, Pakistan & {$[57,63,64]$} \\
\hline 22 & Calotropis gigantea (L.) Ait. f. & Orissa, India & {$[65]$} \\
\hline 23 & Capparis zeylanica $\mathrm{L}$. & West Bengal, India & {$[44]$} \\
\hline 24 & Capsicum annuum $\mathrm{L}$. & India & {$[66]$} \\
\hline 25 & Cassia fistula $\mathrm{L}$. & Karnataka, Tamil Nadu, Uttar Pradesh, India & {$[48,54,62]$} \\
\hline 26 & Cassia occidentalis $\mathrm{L}$. & West Bengal, India & [59] \\
\hline 27 & Cassia sophera $\mathrm{L}$. & West Bengal, India & [39] \\
\hline 28 & Cassia tora L. & Uttaranchal, Uttar Pradesh, India; Brazil & {$[43,48,67]$} \\
\hline 29 & Chenopodium album $\mathrm{L}$. & Islamabad, Pakistan & {$[47]$} \\
\hline 30 & Cissampelos pareira L. & $\begin{array}{l}\text { Rajasthan, West Bengal, Tamil Nadu, India; } \\
\text { Islamabad, Pakistan }\end{array}$ & $\begin{array}{l}{[47,55,68,} \\
\quad 69]\end{array}$ \\
\hline 31 & Clitoria ternatea $\mathrm{L}$. & Madhya Pradesh, Meghalaya, Uttar Pradesh, India & {$[48,70,71]$} \\
\hline 32 & Cynodon dactylon (L.) Pers. & India & {$[72]$} \\
\hline 33 & Cyperus rotundus $\mathrm{L}$. & Madhya Pradesh, India & {$[71]$} \\
\hline 34 & Datura metel L. & Nicobar, Uttar Pradesh, India & {$[48,51]$} \\
\hline 35 & Eclipta prostrata $\mathrm{L}$. & India; Brazil & {$[43,72]$} \\
\hline 36 & Emblica officinalis Gaertn. & Maharashtra, India & [73] \\
\hline 37 & Ficus racemosa L. & Rajasthan, India & [74] \\
\hline 38 & Flacourtia indica (Burm. f.) Merr. & Tamil Nadu, India & {$[62]$} \\
\hline 39 & Gmelina arborea L. & West Bengal, India & {$[49]$} \\
\hline 40 & Helicteres isora $\mathrm{L}$. & Uttar Pradesh, India & {$[48]$} \\
\hline 41 & Hemidesmus indicus (L.) R. Br. & West Bengal, India; Sri Lanka & {$[55,75]$} \\
\hline 42 & Holarrhena antidysenterica (Heyne ex Roth.) Conessi & Orissa, India & {$[65]$} \\
\hline 43 & Holarrhena pubescens (Bach.-Ham.) Wall. & West Bengal, India & {$[44,49]$} \\
\hline 44 & Hyptis suaveolens (L.) Poit. & Uttar Pradesh, India & {$[48]$} \\
\hline 45 & Ichnocarpus frutescens (L.) Br. & West Bengal, India & {$[44]$} \\
\hline
\end{tabular}


TABle 4: Continued.

\begin{tabular}{|c|c|c|c|}
\hline $\begin{array}{l}\text { Serial } \\
\text { number }\end{array}$ & Scientific name of the plant & Region/country & Reference(s) \\
\hline 46 & Lantana camara $\mathrm{L}$. & Madhya Pradesh, India & [71] \\
\hline 47 & Mangifera indica $\mathrm{L}$. & Uttar Pradesh, India & {$[76]$} \\
\hline 48 & Mimosa pudica L. & Nagaland, Uttar Pradesh, India & {$[48,77]$} \\
\hline 49 & Moringa oleifera Lamk. & Assam, India & {$[78]$} \\
\hline 50 & Mucuna pruriens Baker & Uttar Pradesh, India & {$[48]$} \\
\hline 51 & Ocimum basilicum L. & Uttar Pradesh, India; Brazil & {$[43,48]$} \\
\hline 52 & Oroxylum indicum Vent. & Orissa, India & [79] \\
\hline 53 & Oxalis corniculata $\mathrm{L}$. & Meghalaya, India; Tehsil Chakwal, Pakistan & {$[45,80]$} \\
\hline 54 & Piper nigrum L. & Uttaranchal, India & {$[81]$} \\
\hline 55 & Plumbago zeylanica L. & Tripura, India & {$[82]$} \\
\hline 56 & Rauvolfia serpentina (L.) Benth. ex Kurz & Karnataka, Tamil Nadu, Uttar Pradesh, India & {$[48,83,84]$} \\
\hline 57 & Sida acuta Burm. & Madhya Pradesh, India & [71] \\
\hline 58 & Sida cordifolia L. & Rajasthan, Tamil Nadu, India & {$[52,84]$} \\
\hline 59 & Syzygium cumini (L.) Skeels. & Orissa, India & {$[85]$} \\
\hline 60 & Tamarindus indica $\mathrm{L}$. & Maharashtra, India; Africa; Sudan & {$[75,86]$} \\
\hline 61 & Terminalia arjuna (Roxb.) Wt. \& Arn. & West Bengal, India & {$[49]$} \\
\hline 62 & Tinospora cordifolia (Willd.) Miers & Madhya Pradesh, Tamil Nadu, Uttar Pradesh, India & {$[62,76,87]$} \\
\hline 63 & Tylophora indica (Burm. f.) Merrill. & Karnataka, India & {$[54]$} \\
\hline 64 & Urena lobata $\mathrm{L}$ & Tamil Nadu, India & {$[88]$} \\
\hline 65 & Vitex negundo L. & Himachal Pradesh, Kerala, India & {$[89,90]$} \\
\hline 66 & Withania somnifera (L.) Dunal & Karnataka, India; Pakistan & {$[58,75]$} \\
\hline
\end{tabular}

TABLE 5: Literature study of the plants surveyed having toxicity.

\begin{tabular}{|c|c|c|c|c|}
\hline Scientific name & Toxic part & Toxic compound & Toxic effect & Reference \\
\hline $\begin{array}{l}\text { Abrus precatorius } \\
\text { L. }\end{array}$ & Seed & Abrin, ricin & $\begin{array}{l}\text { Abortifacient, inhibiting } \\
\text { cell protein synthesis }\end{array}$ & {$[91]$} \\
\hline Acorus calamus L. & Seed & Beta-asarone & Procarcinogenic & {$[92,93]$} \\
\hline $\begin{array}{l}\text { Ageratum } \\
\text { conyzoides L. }\end{array}$ & Seed & $\begin{array}{l}\text { Pyrrolizidine alkaloids } \\
\text { lycopsamine, echinatine }\end{array}$ & Liver lesions and tumors & {$[94-96]$} \\
\hline $\begin{array}{l}\text { Annona squamosa } \\
\text { L. }\end{array}$ & Root, seed & Annonastin, squamozin & $\begin{array}{l}\text { Roots are drastic purgative } \\
\text { and seeds are strong eye } \\
\text { irritant, abortifacient }\end{array}$ & {$[97]$} \\
\hline $\begin{array}{l}\text { Argemone } \\
\text { mexicana L. }\end{array}$ & Seed, latex & $\begin{array}{c}\text { Sanguinarine, } \\
\text { dihydrosanguinarine }\end{array}$ & Epidemic dropsy & {$[98-101]$} \\
\hline $\begin{array}{l}\text { Bacopa monnieri } \\
\text { (L.) Pennell }\end{array}$ & Whole plant & & $\begin{array}{c}\text { Suppress spermatogenesis } \\
\text { and fertility, digestive } \\
\text { problem }\end{array}$ & {$[102,103]$} \\
\hline $\begin{array}{l}\text { Calotropis gigantea } \\
\text { (L.) Ait. f. }\end{array}$ & Root & Calotropin & $\begin{array}{c}\text { Inhibit spermatogenesis, } \\
\text { abortifacient }\end{array}$ & {$[104]$} \\
\hline $\begin{array}{l}\text { Calotropis procera } \\
\text { (Ait.) Ait. f. }\end{array}$ & Root & $\begin{array}{l}\text { Cytotoxin, calotropin, } \\
\text { calcilin, gigantin }\end{array}$ & Ocular toxicity & {$[105]$} \\
\hline $\begin{array}{l}\text { Cassia occidentalis } \\
\text { L. }\end{array}$ & $\begin{array}{c}\text { Pods and } \\
\text { beans }\end{array}$ & Pyrrolizidine alkaloid & Hepatotoxic & {$[106-108]$} \\
\hline $\begin{array}{l}\text { Catharanthus } \\
\text { roseus (L.) G. Don. }\end{array}$ & Root, shoot & Vincristine, vinblastine & $\begin{array}{l}\text { Hypotension, neurotoxicity, } \\
\text { anaemia, seizure }\end{array}$ & {$[109]$} \\
\hline Ficus racemosa L. & Bark & $\begin{array}{c}\text { Tetracyclic triterpene } \\
\text { derivatives }\end{array}$ & $\begin{array}{l}\text { Cause abnormality of liver } \\
\text { and kidney }\end{array}$ & {$[110]$} \\
\hline Lantana camara & Leaf & Triterpene acids & Leaf extracts are cytotoxic & {$[111]$} \\
\hline
\end{tabular}




\section{Conflict of Interests}

The authors declare that there is no conflict of interests regarding the publication of this paper.

\section{Acknowledgments}

The authors acknowledge the contribution of all the traditional medicine practitioners and indigenous people for providing relevant information regarding medicinal plants and their practices. The authors also express appreciation to all the government and nongovernment authorities for their help and the administrative facilities during the survey.

\section{References}

[1] A. Kasturiratne, A. R. Wickremasinghe, N. de Silva et al., "The global burden of snakebite: a literature analysis and modelling based on regional estimates of envenoming and deaths," PLoS Medicine, vol. 5, no. 11, article e218, 2008.

[2] F. E. Russell, "When a snake strikes," Emergency Medicine, vol. 22, no. 12, pp. 33-43, 1990.

[3] B. S. Gold, R. C. Dart, and R. A. Barish, "Bites of venomous snakes," The New England Journal of Medicine, vol. 347, no. 5, pp. 347-356, 2002.

[4] D. A. Warrell, "Snake bite," The Lancet, vol. 375, no. 9708, pp. 77-88, 2010.

[5] I. D. Simpson and R. L. Norris, "Snakes of medical importance in India: is the concept of the 'Big 4' still relevant and useful?" Wilderness and Environmental Medicine, vol. 18, no. 1, pp. 2-9, 2007.

[6] L. R. Sharma, V. Lal, and I. D. Simpson, "Snakes of medical significance in India: the first reported case of envenoming by the levantine viper (Macrovipera lebetina)," Wilderness and Environmental Medicine, vol. 19, no. 3, pp. 195-198, 2008.

[7] E. Alirol, S. K. Sharma, H. S. Bawaskar, U. Kuch, and F. Chappuis, "Snake bite in south asia: a review," PLoS Neglected Tropical Diseases, vol. 4, no. 1, article e603, 2010.

[8] F. González-Andrade and J.-P. Chippaux, "Snake bite envenomation in Ecuador," Transactions of the Royal Society of Tropical Medicine and Hygiene, vol. 104, no. 9, pp. 588-591, 2010.

[9] F. N. Oliveira, M. T. Brito, I. C. O. de Morais, S. M. L. Fook, and H. N. de Albuquerque, "Accidents caused by Bothrops and Bothropoides in the state of Paraiba: epidemiological and clinical aspects," Revista da Sociedade Brasileira de Medicina Tropical, vol. 43, no. 6, pp. 662-667, 2010.

[10] R. Rahman, M. A. Faiz, S. Selim et al., "Annual incidence of snake bite in rural Bangladesh," PLoS Neglected Tropical Diseases, vol. 4, no. 10, article e860, 2010.

[11] S. Chattopadhyay and B. Sukul, "A profile of fatal snake bite cases in the Bankura district of West Bengal," Journal of Forensic and Legal Medicine, vol. 18, no. 1, pp. 18-20, 2011.

[12] P. Bhattacharjee and D. Bhattacharyya, "Characterization of the aqueous extract of the root of Aristolochia indica: evaluation of its traditional use as an antidote for snake bites," Journal of Ethnopharmacology, vol. 145, no. 1, pp. 220-226, 2013.

[13] D. Williams, J. M. Gutiérrez, R. Harrison et al., "The Global Snake Bite Initiative: an antidote for snake bite," The Lancet, vol. 375, no. 9708, pp. 89-91, 2010.
[14] F. Huq, M. A. Islam, M. H. Sarker et al., "Epidemiology of snakebite in Bangladesh," Bangladesh Journal of Zoology, vol. 23, no. 1, pp. 61-64, 1995.

[15] M. T. Miah, A. A. Hoque, B. K. Tarafder et al., "Epidemiology, clinical profile and outcome of patients of snake bite in Mymensingh Medical College Hospital," Journal of Bangladesh College of Physicians and Surgeons, vol. 27, no. 2, pp. 70-75, 2009.

[16] R. Otero, R. Fonnegra, S. L. Jiménez et al., "Snakebites and ethnobotany in the northwest region of Colombia. Part I: traditional use of plants," Journal of Ethnopharmacology, vol. 71, no. 3, pp. 493-504, 2000.

[17] J. M. Gutierrez and B. Lomonte, "Efectos locales en el envenenamiento ofídico en América Latina," in Animais Peçonhentos no Brasil. Biologia, Clínica e Terapêutica dos Acidentes, Sarvier, Sao Paulo, Brazil, 2003.

[18] R. D. G. Theakston and D. A. Warrell, "Crisis in snake antivenom supply for Africa," The Lancet, vol. 356, no. 9247, article 2104, 2000.

[19] R. Reyes-Chilpa, F. Gómez-Garibay, L. Quijano, G. A. MagosGuerrero, and T. Ríos, "Preliminary results on the protective effect of (-)-edunol, a pterocarpan from Brongniartia podalyrioides (Leguminosae), against Bothrops atrox venom in mice," Journal of Ethnopharmacology, vol. 42, no. 3, pp. 199-203, 1994.

[20] V. Núñez, R. Otero, J. Barona et al., "Neutralization of the edema-forming, defibrinating and coagulant effects of Bothrops asper venom by extracts of plants used by healers in Columbia," Brazilian Journal of Medical and Biological Research, vol. 37, no. 7, pp. 969-977, 2004.

[21] J. O. da Silva, R. S. Fernandes, F. K. Ticli et al., "Triterpenoid saponins, new metalloprotease snake venom inhibitors isolated from Pentaclethra macroloba," Toxicon, vol. 50, no. 2, pp. 283291, 2007.

[22] B. Lomonte, G. León, Y. Angulo, A. Rucavado, and V. Núñez, "Neutralization of Bothrops asper venom by antibodies, natural products and synthetic drugs: contributions to understanding snake bite envenoming and their treatment," Toxicon, vol. 54, no. 7, pp. 1012-1028, 2009.

[23] C. Muthu, M. Ayyanar, N. Raja, and S. Ignacimuthu, "Medicinal plants used by traditional healers in Kancheepuram district of Tamil Nadu, India," Journal of Ethnobiology and Ethnomedicine, vol. 2, article 43, 2006.

[24] R. Govaerts, "How many species of seed plants are there?" Taxon, vol. 50, no. 4, pp. 1085-1090, 2001.

[25] U. Schippmann, D. J. Leaman, and A. B. Cunningham, "Impact of cultivation and gathering of medicinal plants on biodiversity: global trends and issues," in Proceedings of the Satellite Event on the Occasion of the 9th Regular Session of the Commission on Genetic Resources for Food and Agriculture, Inter-Departmental Working Group on Biological Diversity for Food and Agriculture, Rome, Italy, October 2002.

[26] K. Rogo, "Traditional medicine and sustainable development," in Proceedings of the Workshop on Traditional Medicine and Sustainable Development, Nairobi, Kenya, June 2004.

[27] Asiatic Society of Bangladesh, Banglapedia: National encyclopedia of Bangladesh, Asiatic Society of Bangladesh, Dhaka, Bangladesh, 2003.

[28] M. M. K. Mia, Traditional Medicines of Bangladesh, Jahangirnagar University, Dhaka, Bangladesh, 1990.

[29] M. Yusuf, J. Begum, M. N. Hoque, and J. U. Chowdhury, Medicinal Plants of Bangladesh, Bangladesh Council of Scientific and Industrial Research, Dhaka, Bangladesh, 2009. 
[30] M. F. Kadir, M. S. B. Sayeed, and M. M. K. Mia, "Ethnopharmacological survey of medicinal plants used by traditional healers in Bangladesh for gastrointestinal disorders," Journal of Ethnopharmacology, vol. 147, no. 1, pp. 148-156, 2013.

[31] F. G. Coe and G. J. Anderson, "Snakebite ethnopharmacopoeia of eastern Nicaragua," Journal of Ethnopharmacology, vol. 96, no. 1-2, pp. 303-323, 2005.

[32] J. Vásquez, S. L. Jiménez, I. C. Gómez et al., "Snakebites and ethnobotany in the eastern region of Antioquia, Colombiathe traditional use of plants," Journal of Ethnopharmacology, vol. 146, no. 2, pp. 449-455, 2013.

[33] B. O. Owuor and D. P. Kisangau, "Kenyan medicinal plants used as antivenin: a comparison of plant usage," Journal of Ethnobiology and Ethnomedicine, vol. 2, no. 1, article 7, 2006.

[34] R. P. Samy, M. M. Thwin, P. Gopalakrishnakone, and S. Ignacimuthu, "Ethnobotanical survey of folk plants for the treatment of snakebites in Southern part of Tamilnadu, India," Journal of Ethnopharmacology, vol. 115, no. 2, pp. 302-312, 2008.

[35] T. Thirumalai, E. K. Elumalai, S. V. Therasa, B. Senthilkumar, and E. David, "Ethnobotanical survey of folklore plants for the treatment of jaundice and snakebites in Vellore Districts of Tamilnadu, India," Ethnobotanical Leaflets, vol. 14, pp. 529-536, 2010.

[36] CIA, The World Fact Book, CIA, 2012.

[37] C. M. Cotton, Ethnobotany: Principle and Application, John Wiley and Sons, New York, NY, USA, 1996.

[38] A. Bruni, M. Ballero, and F. Poli, "Quantitative ethnopharmacological study of the Campidano Valley and Urzulei district, Sardinia, Italy, Journal of Ethnopharmacology, vol. 57, no. 2, pp. 97-124, 1997.

[39] K. P. Biswas and E. Ghosh, "Bharatya Banaushadhi," in A Treatise on Medicinal Plants, Volume I \& II, Calcutta University Press, Kolkata, India, 1951.

[40] D. N. G. Bakshi, P. Sensharma, and D. C. Pal, A Lexicon of Medicinal Plants in India, Volume I \& II, Naya Prakash, Kolkata, India, 2001.

[41] A. K. Das and H. Tag, "Ethnomedicinal studies of the Khamti tribe of Arunachal Pradesh," Indian Journal of Traditional Knowledge, vol. 5, no. 3, pp. 317-322, 2006.

[42] D. C. Pal and S. K. Jain, Tribal Medicine, Naya Prakash, Kolkata, India, 1998.

[43] W. B. Mors, M. C. Nascimento, B. M. R. Pereira, and N. A. Pereira, "Plant natural products active against snake bite-the molecular approach," Phytochemistry, vol. 55, no. 6, pp. 627$642,2000$.

[44] M. B. Siddiqui and W. Hussain, "Traditional antidote of snake poison in Northern India," Fitoterapia, vol. 61, no. 1, pp. 41-44, 1990.

[45] S. Jeeva, B. P. Mishra, N. Venugopal et al., "Traditional knowledge and biodiversity conservation in the sacred groves of Meghalaya," Indian Journal of Traditional Knowledge, vol. 5, no. 4, pp. 562-568, 2006.

[46] S. S. Ahmad, "Medicinal wild plants from Lahore-Islamabad motorway (M-2)," Pakistan Journal of Botany, vol. 39, no. 2, pp. 355-375, 2007.

[47] A. Jabeen, M. A. Khan, M. Ahmad et al., "Indigenous uses of economically important flora of Margallah Hills National Park, Islamabad, Pakistan," African Journal of Biotechnology, vol. 8, no. 5, pp. 763-784, 2009.

[48] P. K. Singh, V. Kumar, R. K. Tiwari et al., "Medico-ethnobotany of Chatara block of district Sonebhadra, Uttar Pradesh, India," Advances in Biological Research, vol. 4, no. 1, pp. 65-80, 2010.
[49] A. Bandyopadhyay, "Traditional knowledge in utilizing plant biodiversity for snake bite," in Proceedings of the 2002 National Seminar, ISM \& H. R. K. Ashrama, Narendrapur, India, 2002.

[50] D. Shekhawat and A. Batra, "Household remedies of Keshavraipatan Tehsil of Bundi district, Rajasthan," Indian Journal of Traditional Knowledge, vol. 5, no. 3, pp. 362-367, 2006.

[51] C. Verma, S. Bhatia, and S. Srivastava, "Traditional medicine of the Nicobarese," Indian Journal of Traditional Knowledge, vol. 9, no. 4, pp. 779-785, 2010.

[52] S. C. Jain, R. Jain, and R. Singh, "Ethnobotanical survey of Sariska and Siliserh regions from Alwar district of Rajasthan, India," Ethnobotanical Leaflets, vol. 13, pp. 171-188, 2009.

[53] D. K. Tiwari and A. Yadav, "Ethnobotanical investigation of some medicinal plants availed by Gond tribe of Naoradehi wild life sanctuary, Madhya Pradesh," Anthropologist, vol. 5, no. 3, pp. 201-202, 2003.

[54] P. Prashantkumar and G. M. Vidyasagar, "Documentation of traditional knowledge on medicinal plants of Bidar district, Karnataka," Indian Journal of Traditional Knowledge, vol. 5, no. 3, pp. 295-299, 2006.

[55] M. K. Chakraborty and A. Bhattacharjee, "Some common ethnomedicinal uses of various diseases in Purulia district, West Bengal," Indian Journal of Traditional Knowledge, vol. 5, no. 4, pp. 554-558, 2006.

[56] A. B. Prusti and K. K. Behera, "Ethnobotanical exploration of Malkangiri district of Orissa, India," Ethnobotanical Leaflets, vol. 11, pp. 122-140, 2007.

[57] C. Alagesaboopathi, "Ethnomedicinal plants and their utilization by villagers in Kumaragiri hills of Salem district of Tamilnadu, India," African Journal of Traditional, Complementary and Alternative Medicines, vol. 6, no. 3, pp. 222-227, 2009.

[58] H. M. Prakasha, M. Krishnappa, Y. L. Krishnamurthy, and S. V. Poornima, "Folk medicine of NR Pura taluk in Chikmagalur district of Karnataka," Indian Journal of Traditional Knowledge, vol. 9, no. 1, pp. 55-60, 2010.

[59] J. Sekhar, P. G. Pratap, G. Sundarsanam, and G. P. Prasad, "Ethnic information or treatment for snake bite in Kadapa districts of Andhra Pradesh," Life Science Leafllets, vol. 12, pp. 368-375, 2011.

[60] R. Acharya and K. P. Acharya, "Ethnobotanical study of medicinal plants used by Tharu community of Parroha VDC, Rupandehi district, Nepal," Scientific World, vol. 7, no. 7, pp. 80-84, 2009.

[61] S. S. Ahmad, F. Mahmood, Z. Dogar et al., "Prioritization of medicinal plants of Margala Hills National Park, Islamabad on the basis of available information," Pakistan Journal of Botany, vol. 41, no. 5, pp. 2105-2114, 2009.

[62] K. Kadavul and A. K. Dixit, "Ethnomedicinal studies of the woody species of Kalrayan \& Shervarayan hills, Eastern Ghats, Tamil Nadu," Indian Journal of Traditional Knowledge, vol. 8, no. 4, pp. 592-597, 2009.

[63] S. Kumar, S. Goyal, A. Chauhan, and F. Parveen, "Some new ethnomedicinal uses of Milkweed in the Indian desert," Indian Journal of Traditional Knowledge, vol. 4, no. 4, pp. 448-455, 2005.

[64] R. B. Tareen, T. Bibi, M. A. Khan et al., "Indigenous knowledge of folk medicine by the women of Kalat and Khuzdar regions of Balochistan, Pakistan," Pakistan Journal of Botany, vol. 42, no. 3, pp. 1465-1485, 2010.

[65] A. B. Prusti and K. K. Behera, "Ethno-medico botanical study of Sundargarh district, Orissa, India," Ethnobotanical Leaflets, vol. 11, pp. 148-163, 2007. 
[66] C. Kadel and A. K. Jain, "Folklore claims on snakebite among some tribal communities of Central India," Indian Journal of Traditional Knowledge, vol. 7, no. 2, pp. 296-299, 2008.

[67] V. P. Bhatt and G. C. S. Negi, "Ethnomedicinal plant resources of Jaunsari tribe of Garhwal Himalaya, Uttaranchal," Indian Journal of Traditional Knowledge, vol. 5, no. 3, pp. 331-335, 2006.

[68] S. S. Katewa and P. K. Galav, "Additions to the traditional folk herbal medicines from Shekhawati region of Rajasthan," Indian Journal of Traditional Knowledge, vol. 5, no. 4, pp. 494-500, 2006.

[69] S. Sankaranarayanan, P. Bama, J. Ramachandran et al., "Ethnobotanical study of medicinal plants used by traditional users in Villupuram district of Tamil Nadu, India," Journal of Medicinal Plants Research, vol. 4, no. 12, pp. 1089-1101, 2010.

[70] V. Jaiswal, "Culture and ethnobotany of Jaintia tribal community of Meghalaya, Northeast India-a mini review," Indian Journal of Traditional Knowledge, vol. 9, no. 1, pp. 38-44, 2010.

[71] A. N. Shukla, S. Srivastava, and A. K. S. Rawat, "An ethnobotanical study of medicinal plants of Rewa district, Madhya Pradesh," Indian Journal of Traditional Knowledge, vol. 9, no. 1, pp. 191202, 2010.

[72] S. Kumar and S. Narain, "Herbal remedies of wetlands macrophytes in India," International Journal of Pharma and BioSciences, vol. 1, no. 2, pp. 1-12, 2010.

[73] M. V. Patil and D. A. Patil, "Ethnomedicinal practices of Nasik district, Maharastra," Indian Journal of Traditional Knowledge, vol. 4, no. 3, pp. 287-290, 2005.

[74] A. Nag, P. Galav, and S. S. Katewa, "Indegenous animal healthcare practices from Udaipur district, Rajasthan," Indian Journal of Traditional Knowledge, vol. 6, no. 4, pp. 583-588, 2007.

[75] K. Das, "Medicinal plants for snake bite treatment-future focus," Ethnobotanical Leaflets, vol. 13, pp. 508-521, 2009.

[76] A. Kumar, D. D. Tewari, and J. P. Tewari, "Ethnomedicinal knowledge among Tharu tribe of Devipatan division," Indian Journal of Traditional Knowledge, vol. 5, no. 3, pp. 310-313, 2006.

[77] N. S. Jamir, Takatemjen, and Limasemba, "Traditional knowledge of Lotha-Naga tribes in Wokha district, Nagaland," Indian Journal of Traditional Knowledge, vol. 9, no. 1, pp. 45-48, 2010.

[78] J. Purkayastha and S. C. Nath, "Biological activities of ethnomedicinal claims of some plant species of Assam," Indian Journal of Traditional Knowledge, vol. 5, no. 2, pp. 229-236, 2006.

[79] F. M. Franco and D. Narasimhan, "Plant names and uses as indicators of knowledge pattern," Indian Journal of Traditional Knowledge, vol. 8, no. 4, pp. 645-648, 2009.

[80] R. Qureshi, A. Waheed, M. Arshad, and T. Umbreen, "Medicoethnobotanical inventory of Tehsil Chakwal, Pakistan," Journal of Botany, vol. 41, no. 2, pp. 529-538, 2009.

[81] L. Tiwari and P. C. Pande, "Traditional veterinary practices in south eastern part of Chamoli district, Uttaranchal," Indian Journal of Traditional Knowledge, vol. 3, no. 4, pp. 397-406, 2004.

[82] K. Majumdar, R. Saha, B. K. Datta, and T. Bhakta, "Medicinal plants prescribed by different tribal and nontribal medicine men of Tripura state," Indian Journal of Traditional Knowledge, vol. 5, no. 4, pp. 559-562, 2006.

[83] M. Parinitha, G. U. Harish, N. C. Vivek et al., "Ethno-botanical wealth of Bhadra wildlife sanctuary in Karnataka," Indian Journal of Traditional Knowledge, vol. 3, no. 1, pp. 37-50, 2004.

[84] S. Jeeva, S. Kiruba, B. P. Mishra et al., "Weeds of Kanyakumari district and their value in rural life," Indian Journal of Traditional Knowledge, vol. 5, no. 4, pp. 501-509, 2006.
[85] S. Nayak, S. K. Behera, and M. K. Misra, "Ethno-medico-botanical survey of Kalahandi district of Orissa," Indian Journal of Traditional Knowledge, vol. 3, no. 1, pp. 72-79, 2004.

[86] S. Pawar and D. A. Patil, "Ethnomedicinal uses of barks in Jalgaon district," Natural Product Radiance, vol. 6, no. 4, pp. 341346, 2007.

[87] D. Jadhav, "Ethnomedicinal plants used by Bhil tribe of Bibdod, Madhya Pradesh," Indian Journal of Traditional Knowledge, vol. 5, no. 2, pp. 263-267, 2006.

[88] M. Ayyanar and S. Ignacimuthu, "Medicinal plants used by the tribals of Tirunelveli hills, Tamil Nadu to treat poisonous bites and skin diseases," Indian Journal of Traditional Knowledge, vol. 4, no. 3, pp. 229-236, 2005.

[89] S. Verma and N. S. Chauhan, "Indegenous medicinal plants knowledge of Kunihar forest division, district Solan, Himachal Pradesh," Indian Journal of Traditional Knowledge, vol. 6, no. 3, pp. 494-497, 2007.

[90] V. P. Silja, K. S. Varma, and K. V. Mohanan, "Ethnomedicinal plant knowledge of the Mullu kuruma tribe of Wayanad district, Kerala," Indian Journal of Traditional Knowledge, vol. 7, no. 4, pp. 604-612, 2008.

[91] K. J. Dickers, S. M. Bradberry, P. Rice, G. D. Griffiths, and J. A. Vale, "Abrin poisoning," Toxicological Reviews, vol. 22, no. 3, pp. 137-142, 2003.

[92] E. K. Weisburger, Natural Carcinogenic Products, Environmental Science \& Technology, ACS Publications, 1979.

[93] R. B. Paneru, G. N. J. Patourel, and S. H. Kennedy, “Toxicity of Acorus calamus rhizome powder from Eastern Nepal to Sitophilus granarius (L.) and Sitophilus oryzae (L.)," Crop Protection, vol. 16, no. 8, pp. 759-763, 1997.

[94] Y. Sani and S. Bahri, "Pathological changes in liver due to the toxicity of Ageratum conyzoides," Penyakit Hewan (Indonesia), vol. 26, no. 48, pp. 64-70, 1994.

[95] P. P. Fu, Y.-C. Yang, Q. Xia, M. W. Chou, Y. Y. Cui, and G. Lin, "Pyrrolizidine alkaloids-tumorigenic components in Chinese herbal medicines and dietary supplements," Journal of Food and Drug Analysis, vol. 10, no. 4, pp. 198-211, 2002.

[96] H. Wiedenfeld, "Plants containing pyrrolizidine alkaloids: toxicity and problems," Food Additives and Contaminants-Part A Chemistry, Analysis, Control, Exposure and Risk Assessment, vol. 28, no. 3, pp. 282-292, 2011.

[97] T. P. Ajesh, M. V. Krishnaraj, M. Prabu, and R. Kumuthakalavalli, "Herbal abortifacients used by Mannan tribes of Kerala, India," International Journal of Pharm Tech Research, vol. 4, no. 3, pp. 1015-1017, 2012.

[98] R. E. Meaker, "Argemone mexicana seed poisoning," South African Medical Journal, vol. 24, no. 18, pp. 331-333, 1950.

[99] S. K. Verma, G. Dev, A. K. Tyagi, S. Goomber, and G. V. Jain, "Argemone mexicana poisoning: autopsy findings of two cases," Forensic Science International, vol. 115, no. 1-2, pp. 135-141, 2001.

[100] B. D. Sharma, S. Malhotra, V. Bhatia, and M. Rathee, "Epidemic dropsy in India," Postgraduate Medical Journal, vol. 75, no. 889, pp. 657-661, 1999.

[101] M. Das and S. K. Khanna, "Clinicoepidemiological, toxicological, and safety evaluation studies on argemone oil," Critical Reviews in Toxicology, vol. 27, no. 3, pp. 273-297, 1997.

[102] K. Pravina, K. R. Ravindra, K. S. Goudar et al., "Safety evaluation of Baco Mind in healthy volunteers: a phase I study," Phytomedicine, vol. 14, no. 5, pp. 301-308, 2007.

[103] A. Singh and S. K. Singh, "Evaluation of antifertility potential of Brahmi in male mouse," Contraception, vol. 79, no. 1, pp. 71-79, 2009. 
[104] R. S. Gupta, N. Sharma, and V. P. Dixit, "Calotropin-a novel compound for fertility control," Ancient Science of Life, vol. 9, no. 4, pp. 224-230, 1990.

[105] P. M. Kuriachen and Y. Dave, "Structural, developmental and histochemical studies in the collectors of Calotropis procera (Asclepiadaceae)," Journal of Phytological Research, vol. 2, pp. 7-14, 1989.

[106] R. J. Huxtable, "Human health implications of pyrrolizidine alkaloids and herbs containing them," in Toxicants of Plant Origin, vol. 1, pp. 42-86, CRC Press, Boca Raton, Fla, USA, 1989.

[107] B. Vanderperren, M. Rizzo, L. Angenot et al., "Acute liver failure with renal impairment related to the abuse of senna anthraquinone glycosides," Annals of Pharmacotherapy, vol. 39, no. 7-8, pp. 1353-1357, 2005.

[108] V. M. Vashishtha, A. Kumar, T. J. John, and N. C. Nayak, "Cassia occidentalis poisoning as the probable cause of hepatomyoencephalopathy in children in western Uttar Pradesh," Indian Journal of Medical Research, vol. 125, no. 6, pp. 756-762, 2007.

[109] G. E. Burrows and R. J. Tyrl, Toxic Plants of North America, Iowa State University Press, Ames, Iowa, USA, 1st edition, 2001.

[110] Jaykaran, P. Bhardwaj, N. Kantharia et al., "Acute toxicity study of an aqueous extract of Ficus racemosa Linn. bark in albino mice," The Internet Journal of Toxicology, vol. 6, no. 1, article 1, 2008.

[111] B. M. Pour, L. Y. Latha, and S. Sasidharan, "Cytotoxicity and oral acute toxicity studies of Lantana camara leaf extract," Molecules, vol. 16, no. 5, pp. 3663-3674, 2011.

[112] M. F. Kadir, M. S. B. Sayeed, T. Shams, and M. M. K. Mia, "Ethnobotanical survey of medicinal plants used by Bangladeshi traditional health practitioners in the management of diabetes mellitus," Journal of Ethnopharmacology, vol. 144, no. 3, pp. 605611, 2012.

[113] R. J. Marles and N. R. Farnsworth, "Antidiabetic plants and their active constituents," Phytomedicine, vol. 2, no. 2, pp. 137-189, 1995.

[114] M. Giday, Z. Asfaw, and Z. Woldu, "Medicinal plants of the Meinit ethnic group of Ethiopia: an ethnobotanical study," Journal of Ethnopharmacology, vol. 124, no. 3, pp. 513-521, 2009.

[115] P. B. Telefo, L. L. Lienou, M. D. Yemele et al., "Ethnopharmacological survey of plants used for the treatment of female infertility in Baham, Cameroon," Journal of Ethnopharmacology, vol. 136, no. 1, pp. 178-187, 2011.

[116] M. F. Kadir, M. S. B. Sayeed, and M. M. K. Mia, "Ethnopharmacological survey of medicinal plants used by indigenous and tribal people in Rangamati, Bangladesh," Journal of Ethnopharmacology, vol. 144, no. 3, pp. 627-637, 2012.

[117] H. Tag, P. Kalita, P. Dwivedi, A. K. Das, and N. D. Namsa, "Herbal medicines used in the treatment of diabetes mellitus in Arunachal Himalaya, northeast, India," Journal of Ethnopharmacology, vol. 141, no. 3, pp. 786-795, 2012.

[118] T. Teklehaymanot, M. Giday, G. Medhin, and Y. Mekonnen, "Knowledge and use of medicinal plants by people around Debre Libanos monastery in Ethiopia," Journal of Ethnopharmacology, vol. 111, no. 2, pp. 271-283, 2007.

[119] S. Ignacimuthu, M. Ayyanar, and K. Sankarasivaraman, "Ethnobotanical study of medicinal plants used by Paliyar tribals in Theni district of Tamil Nadu, India," Fitoterapia, vol. 79, no. 7-8, pp. 562-568, 2008.

[120] J. R. S. Tabuti, C. B. Kukunda, and P. J. Waako, "Medicinal plants used by traditional medicine practitioners in the treatment of tuberculosis and related ailments in Uganda," Journal of Ethnopharmacology, vol. 127, no. 1, pp. 130-136, 2010.
[121] B. Upadhyay, A. K. P. Dhaker, and A. Kumar, "Ethnomedicinal and ethnopharmaco-statistical studies of Eastern Rajasthan, India," Journal of Ethnopharmacology, vol. 129, no. 1, pp. 64-86, 2010.

[122] M. Giday, Z. Asfaw, and Z. Woldu, "Ethnomedicinal study of plants used by Sheko ethnic group of Ethiopia," Journal of Ethnopharmacology, vol. 132, no. 1, pp. 75-85, 2010.

[123] E. Kochva, A. Bdolah, and Z. Wollberg, "Sarafotoxins and endothelins: evolution, structure and function," Toxicon, vol. 31, no. 5, pp. 541-568, 1993.

[124] M. Cintra-Francischinelli, P. Caccin, A. Chiavegato et al., "Bothrops snake myotoxins induce a large efflux of ATP and potassium with spreading of cell damage and pain," Proceedings of the National Academy of Sciences of the United States of America, vol. 107, no. 32, pp. 14140-14145, 2010.

[125] M. Öhler, D. Georgieva, J. Seifert et al., "The venomics of Bothrops alternatus is a pool of acidic proteins with predominant hemorrhagic and coagulopathic activities," Journal of Proteome Research, vol. 9, no. 5, pp. 2422-2437, 2010.

[126] S. Vaiyapuri, S. C. Wagstaff, K. A. Watson, R. A. Harrison, J. M. Gibbins, and E. G. Hutchinson, "Purification and functional characterisation of rhiminopeptidase A, a novel aminopeptidase from the venom of Bitis gabonica rhinoceros," PLoS Neglected Tropical Diseases, vol. 4, no. 8, article e796, 2010.

[127] R. Doley and R. M. Kini, "Protein complexes in snake venom," Cellular and Molecular Life Sciences, vol. 66, no. 17, pp. 28512871, 2009.

[128] C. Teixeira, Y. Cury, V. Moreira, G. Picolo, and F. Chaves, "Inflammation induced by Bothrops asper venom," Toxicon, vol. 54, no. 7, pp. 988-997, 2009.

[129] R. Joseph, S. Pahari, W. C. Hodgson, and R. Manjunatha Kini, "Hypotensive agents from snake venoms," Current Drug Targets-Cardiovascular and Haematological Disorders, vol. 4, no. 4, pp. 437-459, 2004.

[130] R. L. Lewis and L. Gutmann, "Snake venoms and the neuromuscular junction," Seminars in Neurology, vol. 24, no. 2, pp. 175-179, 2004.

[131] E. Tedesco, M. Rigoni, P. Caccin, E. Grishin, O. Rossetto, and C. Montecucco, "Calcium overload in nerve terminals of cultured neurons intoxicated by alpha-latrotoxin and snake $\mathrm{PLA}_{2}$ neurotoxins," Toxicon, vol. 54, no. 2, pp. 138-144, 2009.

[132] B. Blacklow, P. Escoubas, and G. M. Nicholson, "Characterisation of the heterotrimeric presynaptic phospholipase $A_{2}$ neurotoxin complex from the venom of the common death adder (Acanthophis antarcticus)," Biochemical Pharmacology, vol. 80, no. 2, pp. 277-287, 2010.

[133] M. E. Peterson, "Snake bite: coral snakes," Clinical Techniques in Small Animal Practice, vol. 21, no. 4, pp. 183-186, 2006.

[134] S. A. Karsani and I. Othman, "Isolation, complete amino acid sequence and characterization of a previously unreported postsynaptic neurotoxin-alphaN $\mathrm{N}_{3}$, from the venom of Bungarus candidus," Biochemical and Biophysical Research Communications, vol. 389, no. 2, pp. 343-348, 2009.

[135] A. Roy, X. Zhou, M. Z. Chong et al., "Structural and functional characterization of a novel homodimeric three-finger neurotoxin from the venom of Ophiophagus hannah (King cobra)," The Journal of Biological Chemistry, vol. 285, no. 11, pp. 8302$8315,2010$.

[136] F. S. Markland, "Snake venoms and the hemostatic system," Toxicon, vol. 36, no. 12, pp. 1749-1800, 1998. 
[137] G. K. Isbister, "Snakebite doesn’t cause disseminated intravascular coagulation: coagulopathy and thrombotic microangiopathy in snake envenoming," Seminars in Thrombosis and Hemostasis, vol. 36, no. 4, pp. 444-451, 2010.

[138] A. Shirwaikar, K. Rajendran, R. Bodla, and C. D. Kumar, "Neutralization potential of Viper russelli russelli (Russell's viper) venom by ethanol leaf extract of Acalypha indica," Journal of Ethnopharmacology, vol. 94, no. 2-3, pp. 267-273, 2004.

[139] R. M. Kannappa, S. Viswanathan, P. Thirugnanasambantham, and L. Kameswaran, "Effect of Leucas aspera on snake venom poisoning in mice and its possible mechanism of action," Fitoterapia, vol. 64, no. 5, pp. 442-446, 1993.

[140] B. Havsteen, "Flavonoids, a class of natural products of high pharmacological potency," Biochemical Pharmacology, vol. 32, no. 7, pp. 1141-1148, 1983.

[141] Z. E. Selvanayagam, S. G. Gnavavendhan, K. Balakrishna, R. Bhima Rao, and S. Usman Ali, "Survey of medicinal plants with antisnake venom activity in Chengalpattu district, Tamilnadu, India," Fitoterapia, vol. 66, no. 6, pp. 488-494, 1995.

[142] M. H. Borges, D. L. F. Alves, D. S. Raslan et al., "Neutralizing properties of Musa paradisiaca L. (Musaceae) juice on phospholipase $\mathrm{A}_{2}$, myotoxic, hemorrhagic and lethal activities of crotalidae venoms," Journal of Ethnopharmacology, vol. 98, no. 1-2, pp. 21-29, 2005.

[143] M. J. Alcaraz and J. R. S. Hoult, "Effects of hypolaetin8-glucoside and related flavonoids on soybean lipoxygenase and snake venom phospholipase $\mathrm{A}_{2}$, Archives International Pharmacodynamics, vol. 278, no. 1, pp. 4-12, 1985.

[144] P. A. Melo and C. L. Ownby, "Ability of wedelolactone, heparin, and para-bromophenacyl bromide to antagonize the myotoxic effects of two crotaline venoms and their PLA 2 myotoxins," Toxicon, vol. 37, no. 1, pp. 199-215, 1999.

[145] M. I. Alam, B. Auddy, and A. Gomes, "Isolation, purification and partial characterization of viper venom inhibiting factor from the root extract of the Indian medicinal plant sarsaparilla (Hemidesmus indicus R.br.)," Toxicon, vol. 32, no. 12, pp. 15511557, 1994.

[146] M. I. Alam and A. Gomes, "Snake venom neutralization by Indian medicinal plants (Vitex negundo and Emblica officinalis) root extracts," Journal of Ethnopharmacology, vol. 86, no. 1, pp. 75-80, 2003.

[147] J. W. Agoro, "Crystalline caffeic acid derivatives and compositions and method for treating snakebite," US Patent 4,124,724 (Chemical Abstract 90 (1979) 103649f), 1978.

[148] A. Agrawal, I. R. Siddiqui, and J. Singh, "Coumarins from the roots of Feronia limonia," Phytochemistry, vol. 28, no. 4, pp. 1229-1231, 1989.

[149] S. Lee, C. Xiao, and S. Pei, "Ethnobotanical survey of medicinal plants at periodic markets of Honghe Prefecture in Yunnan Province, SW China," Journal of Ethnopharmacology, vol. 117, no. 2, pp. 362-377, 2008.

[150] N. Singh, S. Kumar, P. Singh et al., "Piper longum Linn. Extract inhibits TNF- $\alpha$-induced expression of cell adhesion molecules by inhibiting NF- $\kappa$ B activation and microsomal lipid peroxidation," Phytomedicine, vol. 15, no. 4, pp. 284-291, 2008.

[151] P. A. Shenoy, S. S. Nipate, J. M. Sonpetkar, N. C. Salvi, A. B. Waghmare, and P. D. Chaudhari, "Anti-snake venom activities of ethanolic extract of fruits of Piper longum L. (Piperaceae) against Russell's viper venom: characterization of piperine as active principle," Journal of Ethnopharmacology, vol. 147, no. 2, pp. 373-382, 2013.
[152] M. L. Gujral and S. N. Dhawan, "The effect of drugs modifying absorption on death caused by cobra venom in rats," Indian Journal of Medical Research, vol. 44, no. 4, pp. 625-629, 1956.

[153] C. Z. Oliveira, V. A. Maiorano, S. Marcussi et al., "Anticoagulant and antifibrinogenolytic properties of the aqueous extract from Bauhinia forficata against snake venoms," Journal of Ethnopharmacology, vol. 98, no. 1-2, pp. 213-216, 2005.

[154] A. Dey and J. N. De, "Ethnobotanical survey of Purulia district, West Bengal, India for medicinal plants used against gastrointestinal disorders," Journal of Ethnopharmacology, vol. 143, no. 1, pp. 68-80, 2012.

[155] T. H. Bekalo, S. D. Woodmatas, and Z. A. Woldemariam, "An ethnobotanical study of medicinal plants used by local people in the lowlands of Konta Special Woreda, southern nations, nationalities and peoples regional state, Ethiopia," Journal of Ethnobiology and Ethnomedicine, vol. 5, article 26, 2009. 


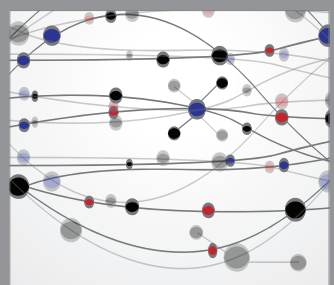

The Scientific World Journal
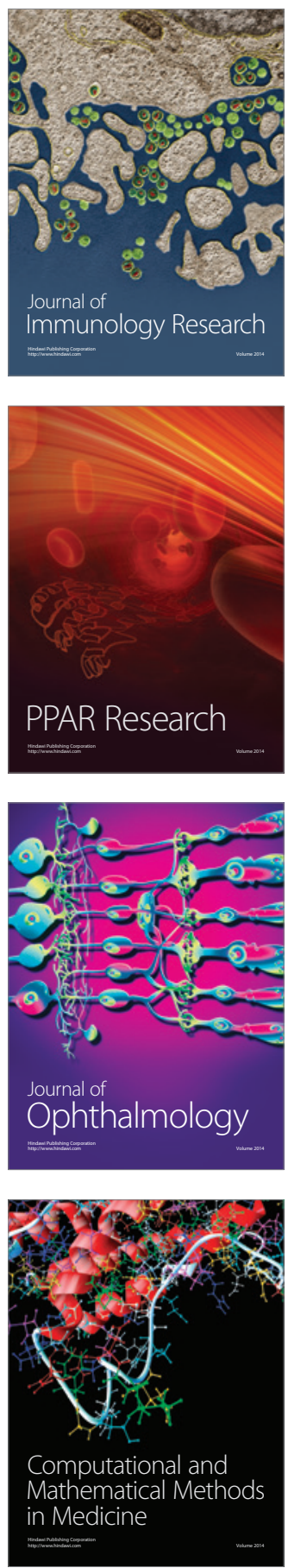

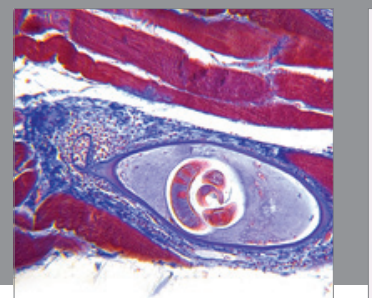

Gastroenterology

Research and Practice
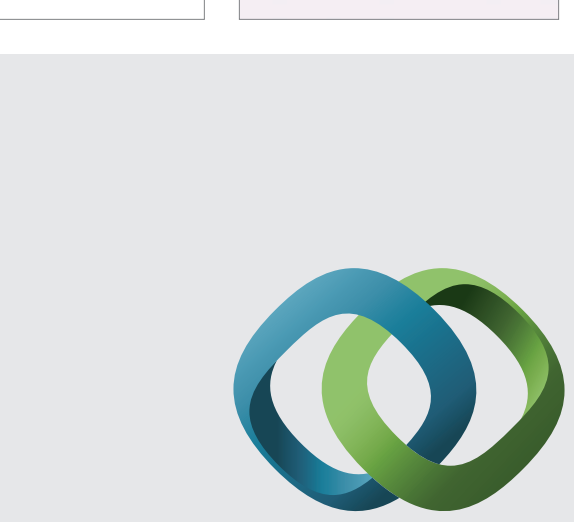

\section{Hindawi}

Submit your manuscripts at

http://www.hindawi.com
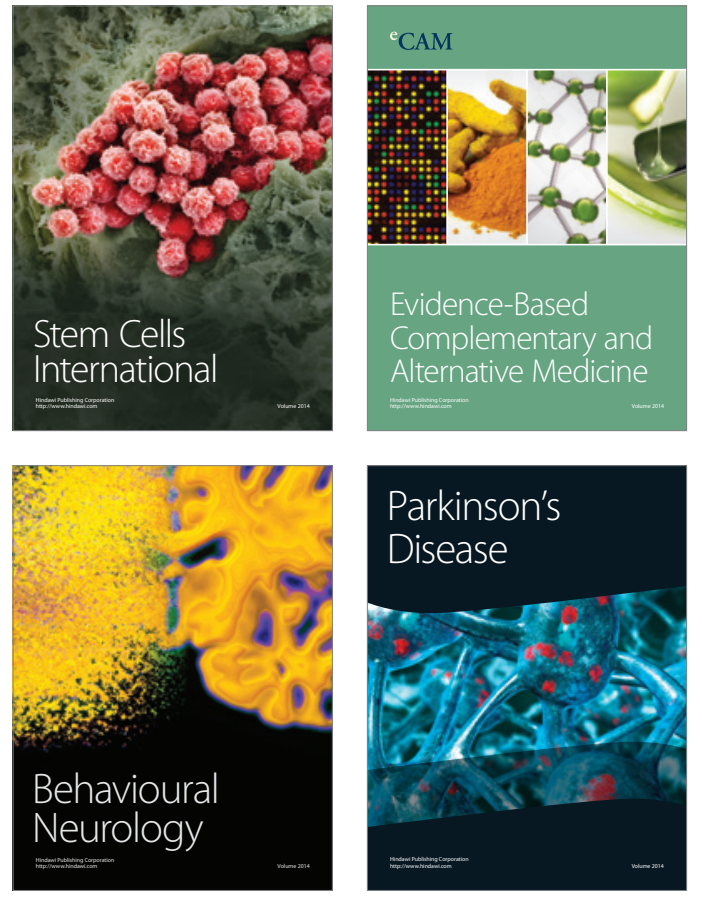
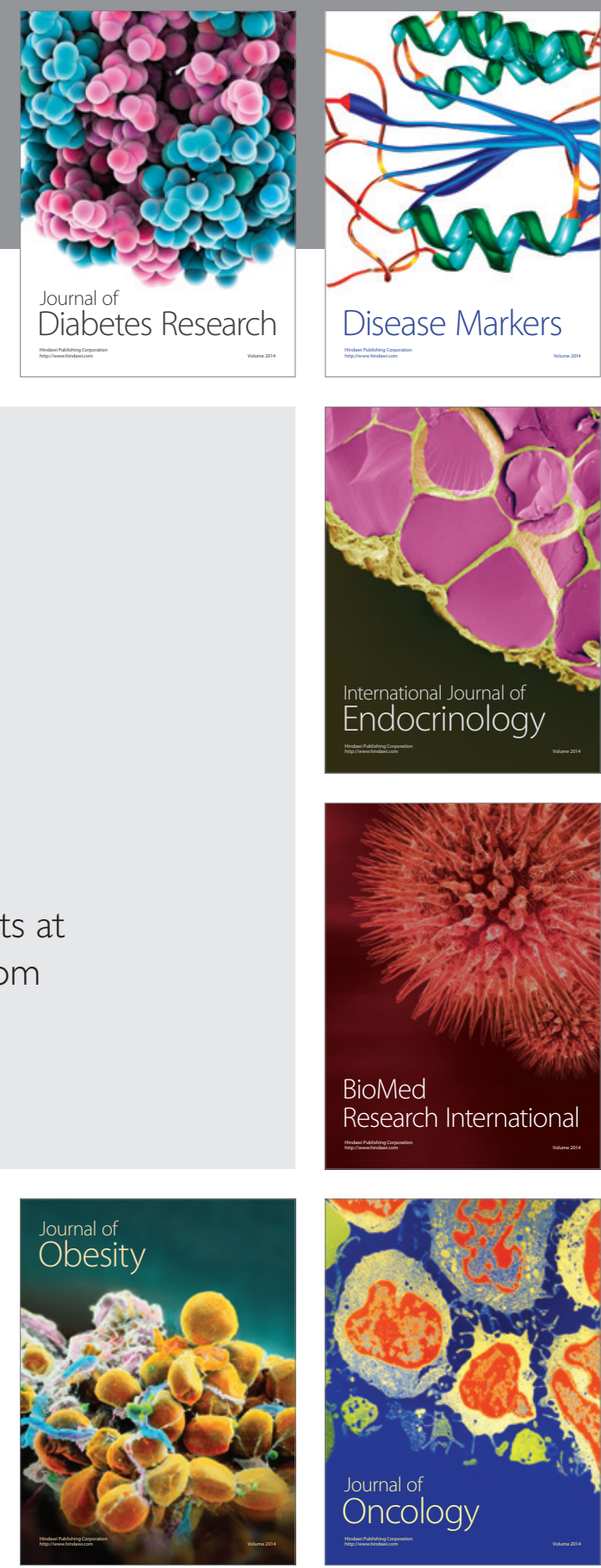

Disease Markers
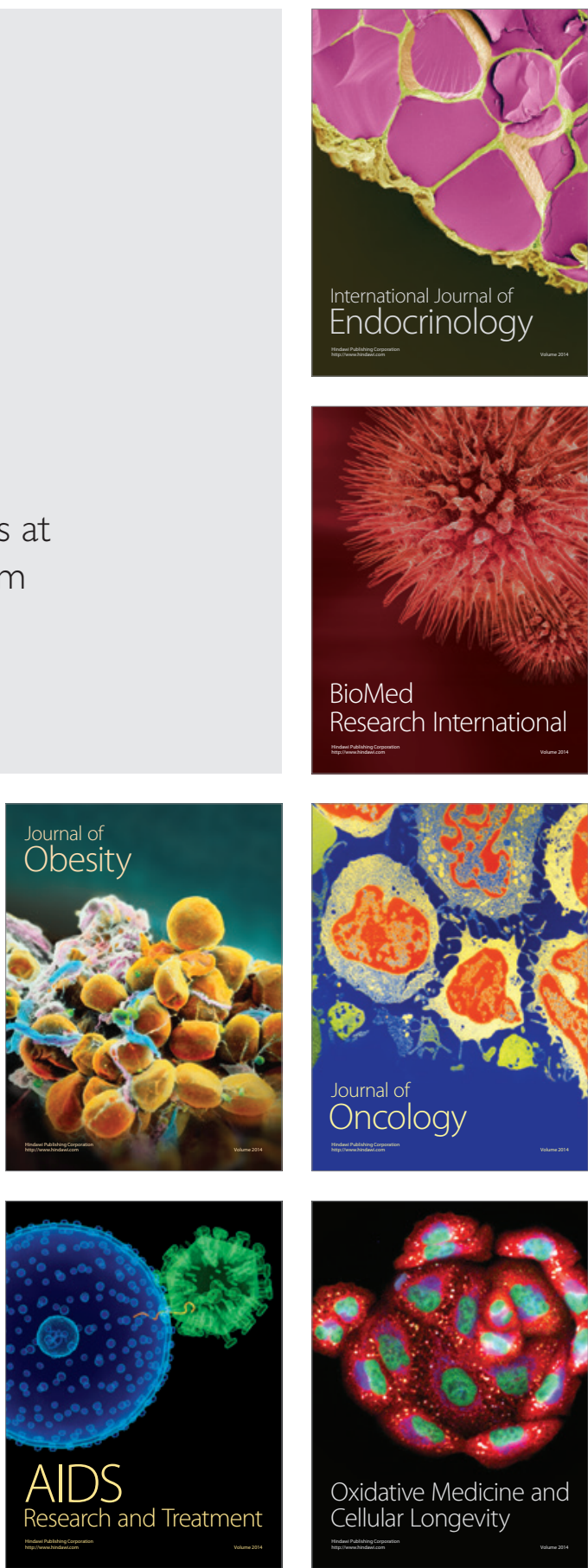